Gender Wage Gap and Segregation in Late Transition

\author{
By: Štěpán Jurajda \\ Working Paper Number 306 \\ May 2000
}




\title{
Gender Wage Gap and Segregation in Late Transition
}

\author{
Štěpán Jurajda \\ CERGE-EI \\ Industrial Relations Section, Princeton University \\ William Davidson Institute, University of Michigan
}

May 2, 2000

\begin{abstract}
Transition countries hoping to join the European Union are in the process of introducing western-type anti-discrimination policies aimed at reducing the gender wage gap. The efficacy of these policies depends on the relative size of the gap's elements they target; therefore, it is important to quantify these parts. In this paper, large matched employer-employee data sets from the Czech Republic and Slovakia are used to provide such detailed gender wage gap decomposition. The results, based on 1998 data, suggest that various forms of workplace segregation are related to about one third of the overall pay difference between genders in both countries. In the non-public sector, however, almost two thirds of the total gap remains attributable to the individual's sex, suggesting much of the gap is due to violations of the equal pay policy.
\end{abstract}

\begin{abstract}
Acknowledgments The author would like to thank Randal Filer, Jan Hanousek, Dean Jolliffe, Jeffrey Kling, and Jan Kmenta for helpful comments on earlier drafts of this paper. I am also grateful for help from Géza Mihály of Trexima, Slovakia, Ján Plánovský, and Vladimír Smolka of Trexima, Czech Republic, and for research assistance from Pavel Č́žcek. Part of this research was carried out while I was a visitor in the Industrial Relations Section, Princeton University and in the William Davidson Institute, University of Michigan, and I would like to thank both institutions for their support and hospitality. This research was supported by the Institute for Human Sciences' SOCO program, which is financed by the Austrian Federal Chancellery's Fund for Cooperation with Central and Eastern Europe and by the Ford Foundation.
\end{abstract}

Address CERGE-EI, POB 882, Politických vězňů 7, Prague, Czech Republic. e-mail: stepan.jurajda@cerge.cuni.cz 


\section{Introduction}

The legislation of most transition economies (TEs) has long included fundamental clauses about equality of men and women. Until recently, however, western-style anti-discrimination labor market policies were either not introduced or enforced. ${ }^{1}$ Since one of the pre-requisites of accession to the European Union is harmonization of legislation, many TEs, including the Czech Republic and Slovakia, are now in the process of enacting policies of comparable worth, equal pay, and equal employment opportunity.

Each of these anti-discrimination policies affects a different source of the overall wage gap between men and women. The comparable worth policy attempts to equalize wage rates across occupations and job cells of equal worth, where job cell is defined as a group of workers with the same occupation within a firm and "worth" is defined in terms of the job's skill requirements and other attributes. The equal pay provisions target wage differences within job cells. Finally, the equal employment opportunity clauses affect all forms of segregation-the discriminatory hiring, firing, and promotion practices that result in high concentration of women in low-paying occupations, firms, or job cells. Which of the anti-discrimination policies is the most important in narrowing the gender wage gap therefore depends on the relative size of the gap's elements.

Occupational segregation has been the subject of much research, e.g. Killingsworth (1990) and Macpherson and Hirsh (1995), which finds that not only female, but also male wages are lower in predominantly female occupations. Johnson and Solon (1986) suggest that employer segregation in the U.S. may be more important than occupational segregation, implying the comparable worth policy applied within firms has little effect. Further, Blau (1977) and Bielby and Baron (1984) point to the presence of significant job-cell segregation. ${ }^{2}$ Matched employer-employee data-sets now allow

\footnotetext{
${ }^{1}$ The constitutions of TEs typically include a "no discrimination in remuneration" clause and in some countries, e.g. Ukraine, Estonia, and Hungary, the Labor Law guarantees "equality of labor rights." However, these rights are not specified in detail and not enforced in courts. For example, until recently Czech employers stated gender requirements when posting hiring ads, etc.

${ }^{2} \mathrm{~A}$ recent survey of the gender-related economic literature is provided in Altonji and Blank (in press).
} 
researchers to simultaneously condition on the extent of all of these types of gender segregation when estimating the effect of gender on wages. See Groshen (1991), Carrington and Troske (1998), and Bayard et al. (1999) for analysis of such data from the U.S. The results of the last study, based on a large data set covering all industries and occupations, suggest that both the effect of the individual's sex within a job cell and various forms of gender segregation are important in accounting for the total gender pay gap.

Even though the pre-accession TEs are now introducing anti-discrimination labor market policies potentially affecting gender employment segregation, little is known about the importance of segregation for the gender wage gap in these countries. There is a wealth of research studying the evolution of gender-specific wages during early transition when wage differentiation increased dramatically and when labor force participation rates decreased from the artificially high levels of the communist era (see Section 2). With one exception, however, this research did not focus on the effects of occupational segregation, and no evidence exists on the contribution to the wage gap of within-establishment and job-cell segregation.

Ogloblin (1999) analyzes gender pay differences and occupational segregation in Russia during 1994-1996 and concludes that most of the total gap is attributable to occupational segregation, a legacy of the Soviet era. Due to the uniformity of labor market practice across the former communist countries, one could expect segregation to have a sizeable effect on gender wage differences in other TEs as well. Understanding and quantifying sources of the wage gap helps to identify the policies most relevant for reducing the gap. In particular, to combat the segregation-related gender pay gap, it is crucial to understand whether it arises within or across firms. It is therefore important to guide the enforcement of the newly introduced anti-discrimination policies in the TEs by decomposing the overall wage gap into its parts which are attributed to detailed forms of gender segregation and to violations of the equal pay act.

This paper provides such decomposition using matched employer-employee data sets including hourly wage records of almost 1 million Czech and Slovak workers in 1998. I follow Groshen (1991) 
and Bayard et al. (1999) and describe the wage structure using wage regressions conditioning not only on the female dummy, but also on the fraction of women within a given occupation, establishment or job cell. The estimated coefficients are used together with the mean differences in explanatory variables by gender to calculate a standard Oaxaca-Blinder mean wage gap decomposition. The regression estimates account for the clustering of regression residuals by firms and for coefficient heterogeneity across sample strata.

To my knowledge this is the first analysis of the gender wage gap in transition countries using a matched employer-employee data set and capturing within-establishment segregation effects. Further, the paper offers separate policy implications for the unregulated non-public sector and for the budgetary public sector, where wages are set according to wage grids specified by the government administration. In spite of the recent work analyzing the gender wage gap in many transition countries (see the next section), this paper also appears to be the first to provide a detailed analysis of the gender wage gap for the Czech and Slovak Republics.

The comparison between these two countries is interesting for at least three reasons. First, until 1993 they formed a federation and shared a common institutional framework, currency, and legal system. Much of this common institutional past remains in place and offers a comparative laboratory which automatically controls for many otherwise elusive country-specific factors. Second, even though the two countries shared similar initial conditions, it is generally acknowledged that transformation from central planning into a market economy (including privatization) started earlier and progressed farther in the Czech Republic (see Svejnar, in press, and the references therein). Third, the unemployment rates were much higher in Slovakia than in the Czech lands from the outset of transition. ${ }^{3}$ The comparison between these countries is therefore one between a rapid and successful reform and a sluggish high-unemployment transformation.

\footnotetext{
${ }^{3}$ The unemployment rates were $4.8 \%$ for Czech men and $7.3 \%$ for Czech women and $12.2 \%$ for Slovak men and 13.4\% for Slovak women in the sample-period quarters of 1998 (see section Data). Ham et al. (1999) provide the time evolution of unemployment in both countries since the beginning of transition.
} 


\section{Background}

At first glance, the level of gender equality under communism has been impressive. Indeed, the equality of men and women was one of the proclaimed advantages of the communist system. The system supporting this equality was, however, authoritative, rather than rights-based. The "full employment" policy stipulated that all able-bodied individuals had to work and wages and prices were set so that only one income per family meant near poverty. Most women therefore worked, ${ }^{4}$ but they also had full access to education and health care. As many other "rights" imposed under central planning, the right to gender equality resulted in what has been sometimes termed an "allergy to feminism." Further, the system included institutionalized attitudes toward treating women as "specific labor force" and often resulted in severe occupational segregation. ${ }^{5}$ See Ogloblin (1999), who provides a detailed discussion of the relevant institutional background on gender in communism.

In accordance with the official policy of gender equality, pay differentiation based on gender was restricted under central planning. Wages were set according to industry-specific wage grids varying only with the difficulty of the job and with the worker's education and experience, not gender (Münich et al., 1999). Even though the possibility of gender wage discrimination was severely limited in communist Czechoslovakia by the imposition of these wage grids, gender wage gaps were substantial. In 1988, women earned on average only 65-71 percent of men's wages (Jackman and Rutkowski, 1994; Ham et al., 1995) and these differences are generally attributed to discriminatory promotion practices and to segregation of women into low-paying occupations.

\footnotetext{
${ }^{4}$ Labor force participation rates were extremely high for both sexes under central planning and declined during early transition. The decline was only somewhat faster for women then for men (see Ham et al., 1999, and the references therein). In 1998, the Czech (Slovak) participation rate for ages 15-64 was 80 (73) percent for men and 64 (60) percent for women.

${ }^{5}$ The past and current Labor Codes of the Czech and Slovak Republics are very similar to labor market legislation of other TEs. They prohibit women from certain types of arduous work and entitle mothers to up to 3 years of maternity leave. See Paukert (1991) for a discussion of gender issues in the Czech labor market.
} 
Following the collapse of communism, wage regulations were quickly abolished and a wealth of studies summarized by Svejnar (in press) documents a rapid increase in wage dispersion during transition, underlined in part by increases in returns to education. ${ }^{6}$ Skill-related wage differentials kept rising even in the mid to late 1990s, but the process seems to have converged to a relatively stable wage structure at least in the Czech Republic and Slovakia (Filer et al., 1999). Today, wage grids, restraining gender pay differentiation, are used only in the budgetary sector (public administration, education, and health), and room for pay discrimination is relatively open in the unregulated non-budgetary sector. This is likely to change with the introduction and enforcement of the western-style anti-discrimination policies.

Recently, the literature investigating the evolution of the wage position of women during transition has rapidly grown. See, e.g., Orazem and Vodopivec (1995) for Slovenia; Hunt (1998) for East Germany; and Newell and Reilly (1996), Brainerd (1998), Reilly (1999), and Ogloblin (1999) for Russia. Hunt first documents a ten percentage point fall in the East German gender pay gap during the first half of the 1990s and then explains $40 \%$ of this rise in relative female wages by the withdrawal from employment of workers earning low wages at the outset of transition. In Russia's early transition, Newell and Reilly (1996) find that little of its 30\% wage gap can be explained by gender differences in productive characteristics, and Reilly (1999) further documents that the overall wage gap in Russia was quite stable between 1992 and 1996, while overall wage inequality increased dramatically. Ogloblin's (1999) study is closely related to the present research in its attempt to capture the effect of occupational segregation on wages. Using a nationally representative Russian household survey from 1992-1996, he finds, similar to Newell and Reilly (1996), that the gender pay gap cannot be explained by gender differences in education and experience alone. Ogloblin then further conditions on industry and firm ownership dummies as well as on a class of

\footnotetext{
${ }^{6}$ Chase (1998) estimates the wage returns to education for Czech and Slovak workers under communism and during early transition. He finds substantial increases in skill wage differentials for both men and women. Even though this increase has been faster for men, returns remain higher for women. This is shown to be in part due to female participation selection effects. According to Filer et al. (1999), returns to education uncorrected for selection remain higher for women than for men in both countries even in the mid-to-late 1990s.
} 
occupational dummies, capturing overwhelmingly "male" and "female" occupations. ${ }^{7}$ He finds that these additional controls account for over $80 \%$ of the overall wage gap and singles out occupational segregation as the most important determinant of gender earnings differentials in Russia.

This study extends the existing literature by controlling for within-establishment forms of workplace segregation, by analyzing gender wage differences in the Czech and Slovak Republics, and by offering recent and policy-targeted evidence on the structure of the gender wage gap in transition countries.

\section{Data}

The data come from national employer surveys, called Information System on Average Earnings (ISAE), in which firms report hourly wages of their employees. ${ }^{8}$ (Both countries also conduct household surveys of individuals, but these Labor Force Surveys do not ask about wages.) For each firm, the data includes the industry of operation and firm's ownership type (private, state, foreign, or mixed), while the region of operation is recorded separately for each establishment of a multiunit firm. Only firms with more than 10 employees are covered in the sample. Participating firms report hourly wages, gender, education, age, and a detailed occupational classification (based on the International Standard Classification of Occupations 1988) for all workers they employ except top management. The data records are drawn directly from companies' personnel databases using software developed by the data-collection agencies. Having available a measure of hourly wage rates is ideal for the purpose of estimating differences in the pay of men and women because of the gender differences in hours worked. Furthermore, the definition of hourly wage is detailed and fully

\footnotetext{
${ }^{7}$ Fifteen such dummy variables are included in his regressions covering all 4-digit occupations within each one-digit occupational group which have more than $70 \%$ of either female or male workers.

${ }^{8}$ The surveys, included by the Czech and Slovak Statistical Offices among the national obligatory inquiries, are collected by a private agency on behalf of the Czech Ministry of Labor and Social Affairs and the Slovak Ministry of Labor, Social Affairs and Family. They are compatible with the European Earnings Cost Index and coordinated by the European Statistical Office.
} 
consistent across firms. ${ }^{9}$ The uniformity of the wage definition and the use of personnel records minimizing the extent of reporting errors make the data unique at least in the transition context.

The data obtained for the analysis consists of employees from participating firms from the first quarter of 1998 for the Czech Republic and a randomly drawn one-in-three sub-sample of employees from Slovak firms from the third quarter of 1998. The original ISAE samples from this period cover approximately 35 and $22 \%$ of the entire Czech and Slovak enterprise employment respectively. In the Czech Republic, the sample includes 1614 firms and establishments, which form a total of 999 firms, some multi-unit. In the Slovak sample, there are 658 firms, consisting of 735 firms and their establishments. ${ }^{10}$

Participating firms were drawn randomly within sampling strata, defined by the product of an industry classification and employment-size categories. However, the strata-specific population coverage, defined as the ratio of the number of sampled establishments to the number of establishments in the economy within a given sampling strata, is the result of a number of discretionary decisions on the part of the data collection agencies. Collection of this data began in 1993 when the sample contained a few large firms. The samples were gradually enlarged in each country by random sampling in strata where coverage was relatively low. This is far from an ideal sampling strategy. It under-represents newly born firms and does not fully correspond to modern probability sampling procedures. The resulting samples lack representativeness with respect to both sampling criteria: the industrial structure and size. The structure of each sample is presented in the appendix Tables A-1 and A-2. The composition of the data is weighted toward large establishments and manufacturing industries, similar to the matched employer-employee data used by Bayard et al. (1999). ${ }^{11}$

\footnotetext{
${ }^{9}$ Each quarter, employers in the Czech and Slovak Republics are legally required to calculate for each worker an average hourly wage, defined as total cash compensation including bonuses and other special payments divided by total hours worked for that quarter. This average wage is then used for calculating sickness and unemployment benefits.

${ }^{10} \mathrm{~A}$ majority of the establishments belongs to few large public or state-owned firms, such as the national railroads.

${ }^{11}$ See Abowd and Kramarz (in press) who provide a survey of the existing matched employer-employee data sets.
} 
The data covers, however, essentially all industries and occupations in both countries. The ISAE samples not only provide the only source of recent wage information in the Czech Republic and Slovakia, but to my knowledge, they are also the only matched employer-employee data from any transition country.

To recover population statistics as closely as possible, weights reflecting the sampling procedure were calculated by dividing the population frequency of firms within strata cells by the corresponding sample frequency. ${ }^{12}$ The population distribution is based on end-of-year firm registers, which are compiled by the Statistical Offices of each country and contain summary information on all existing firms in the economy. ${ }^{13}$ The firm registers are also used as sampling frames by the data collection agencies. Unfortunately, the registers appear to be of problematic quality for the smallest firm-size categories. (Revised statistics are often published with significant delay, which differ greatly from the originally published results.) Further, the ISAE samples include only a very small fraction of existing firms with fewer than 100 employees. The analysis is therefore based on a sample of firms employing more than 100 workers, containing 726,635 workers in 663 Czech firms and 112,698 workers in 443 Slovak firms.

Much of the analysis conditions on the workers' attained education level, ${ }^{14}$ which is however missing for a large fraction of workers (25\% in Czech and $12 \%$ in Slovak data). Education has therefore been imputed based on the in-sample information. Five broad educational attainment categories were formed and the most frequent value for those workers reporting education within 4-digit occupational categories has been assigned as the predicted value separately for each sex and

\footnotetext{
${ }^{12}$ For Slovakia, I also had access to population employment figures by strata. Weights based on strata employment were fully comparable, however, to weights based on the strata-specific number of firms. For the Czech Republic, only the firm frequencies are available; therefore, I use the firm-level weights in both countries.

${ }^{13}$ For the Czech Republic, I use the 1997 register to approximate the population of firms in the first quarter of 1998. For Slovakia, the 1998 register is used to approximate the 3rd quarter 1998 population.

${ }^{14}$ As with most other data from transition economies, education is reported as the highest degree obtained rather than as years of schooling actually attended. See Chase (1998) and Filer et al. (1999) for a brief description of the Czech and Slovak educational system and its several paths that students may follow.
} 
country. The gender mean wage differences by education degree based on either the reported or the imputed measure of education are in most cases almost identical.

Appendix Tables A-2 and A-3 compare weighted and unweighted means based on the ISAE data. Weighting in most cases lowers the mean wage estimate as more weight is given to smaller firms, which pay lower wages. The average hourly wage in the Czech non-public sector decreases by about 6 Czech Crowns (CZK) for both sexes as a result of weighting. The effect is smaller in the Czech public sector and Slovak non-public sector and is actually reversed for public wages in Slovakia, where coverage is much lower than elsewhere. Except for firm total employment, which corresponds to one of the weighting dimensions, other variables are little affected by weighting.

Comparing the two economies, the differences in educational attainment are relatively minor. Both countries shared the same institutional infrastructure until 1993, and one can expect some of this common past to still determine the occupational structure and the patterns of employment by gender. There are more private firms in the Czech economy, however, and a relatively larger portion of the Slovak employment is in state-owned business. This reflects the general progress of marked-oriented transformation in the two countries, mentioned in the introductory section.

\section{Methods}

A vast literature aimed at measuring the extent of wage discrimination has followed Oaxaca (1973) in decomposing the overall mean wage difference between the advantaged (men) and disadvantaged (women) into two parts: the first reflecting the difference in average productive endowments of individuals in each group and the second part due to the differences in coefficients. Following this approach, one first estimates logarithmic wage regressions separately for each gender, controlling for explanatory variables. The decomposition technique relies on the fact that the fitted regressions pass through the sample means as follows:

$$
\overline{\ln w_{j}}={\widehat{\beta_{j}}}^{\prime} \overline{X_{j}}, \quad j \in\{f, m\}
$$


where $f$ denotes females and $m$ denotes males, $\overline{\ln w_{j}}$ is the gender-specific mean of the natural logarithm of hourly wage, and where $\overline{X_{j}}$ are the respective vectors of mean values of explanatory variables for men and women. Finally, $\widehat{\beta_{m}}$ and $\widehat{\beta_{f}}$ are the corresponding vectors of estimated coefficients. A general form of the mean wage decomposition is as follows:

$$
\overline{\ln w_{m}}-\overline{\ln w_{f}}=\left(\overline{X_{m}}-{\overline{X_{f}}}^{\prime}\right)^{\tilde{\beta}}+\left[{\overline{X_{m}}}^{\prime}\left(\widehat{\beta_{m}}-\widetilde{\beta}\right)+{\overline{X_{f}}}^{\prime}\left(\widetilde{\beta}-\widehat{\beta_{f}}\right)\right]
$$

where $\widetilde{\beta}$ represents a counter-factual non-discriminatory wage structure. The first term on the right hand side of equation 2 represents that part of the total logarithmic wage difference which stems from the difference in average productive characteristics across gender. The second term originates in the differences in gender-specific coefficients from the non-discriminatory wage structure and is often interpreted as reflecting wage discrimination. ${ }^{15}$

There are a number of variants of this method depending on how one simulates the nondiscriminatory wage structure. Oaxaca and Ransom (1994) suggest the use of regression coefficients obtained by estimating a wage regression on a pooled data-set including both men and women, arguing that they provide a good estimate of a competitive non-discriminatory norm. I follow their suggestion. In my empirical work, I further assume, following Groshen (1991) and Bayard et al. (1999), that the male and female coefficients are equal (except for the constant term). These two assumptions $\left(\beta_{m}=\beta_{f}=\widetilde{\beta}\right)$ reduce the right hand side of equation 2 to its first term. ${ }^{16}$ Therefore, I initially estimate standard logarithmic wage regressions of the following form:

$$
\ln w_{i j}=\alpha F_{i j}+X_{i j}^{\prime} \beta+\epsilon_{i j}, \text { with } i=1, \ldots N_{j}, \text { and } j=1, \ldots, J
$$

where $w_{i j}$ denotes the hourly wage of the $i$-th worker in the $j$-th firm, and where $F_{i j}=1$ if the worker is female and equals 0 otherwise. $J$ denotes the number of firms in the sample and $N_{j}$ is the

\footnotetext{
${ }^{15}$ There have been objections to this decomposition approach. First, by focusing on the mean gap, it ignores meaningful differences in gender-specific wage distributions. Second, if characteristics which might differ between males and females are omitted in the vector of regressors, the contribution of these characteristics will be captured by the constant term and will erroneously appear in the measure of discrimination.

${ }^{16}$ The equality of female and male coefficients was relaxed by Bayard et al. (1999) without qualitatively affecting their results.
} 
number of workers in the $j$-th firm. Under the assumption of equality of coefficients, the estimated female effect $\widehat{\alpha}$ can be interpreted as the pure (percentage) effect of gender on wages to the extent that the effect of other characteristics have been accounted for by the vector $X_{i j}$, which consists of all other observed worker and firm specific characteristics.

In the next step, I again follow Groshen (1991) and Bayard et al. (1999) in estimating the effect of gender segregation on wages by also conditioning on the "femaleness" of occupations, establishments, and job cells. The extent of segregation is captured by the percent female $(P)$ in a given group of employees:

$$
\ln w_{i j}=\alpha F_{i j}+X_{i j}^{\prime} \beta+P_{i j}^{\prime} \gamma+\epsilon_{i j}
$$

Here, the elements of the $P$ vector are the measures of gender segregation, i.e., the fraction of female employment in the $i j$ worker's occupation, firm, and job cell.

The specific nature of the sampling procedure discussed in Section 3 results in a lack of representativeness of the ISAE data across strata. For instance, small firms, which typically pay lower wages, are relatively under-represented in the samples. This should be reflected in calculating mean wages (and mean wage differences between men and women) by properly re-weighting means from each strata. Weighting in regression, however, is not only an old but also a controversial topic. ${ }^{17}$ Under the assumption that regression coefficients are identical across strata, both OLS and WLS estimators are consistent, and OLS is efficient. If the parameter vectors differ for each sampling strata $s=1, \ldots, S$ so that $\delta_{s} \neq \delta$, where $\delta^{\prime} \equiv\left(\alpha, \beta^{\prime}, \gamma^{\prime}\right)$ from equation 4 , a regression slope estimator analogous to the mean estimator is a weighted average of strata-specific regression estimates:

$$
\widehat{\delta}=\sum_{s=1}^{S} W_{s} \widehat{\delta}_{s}, \quad \widehat{V}(\widehat{\delta})=\sum_{s=1}^{S} W_{s}^{2} \widehat{V}\left(\widehat{\delta}_{s}\right),
$$

where $W_{s}=n^{-1} n_{s}$ are weights reflecting the population shares of employees in each strata, ${ }^{18}$ and

\footnotetext{
${ }^{17}$ This section relies heavily on Deaton (1997, pp. 67-72).

${ }^{18}$ The population counts of employees by strata are not available for the ISAE data and they have to be contructed from the population number of firms by strata, $N_{s}$. Denoting the sample values of strata-specific number of firms and employees as $\widetilde{N_{s}}$ and $\widetilde{n_{s}}$ respectively, I estimate the population counts as $\widehat{n_{s}}=\left(\widetilde{N_{s}}\right)^{-1} N_{s} \widetilde{n_{s}}$ and $\widehat{n}=\sum_{s} \widehat{n_{s}}$.
} 
where $\widehat{\delta}_{s}$ is an OLS estimate based on observations from stratum $s$.

Perhaps surprisingly, the weighted least squares (WLS) procedure applied to pooled data from all strata results in an estimator $\widehat{\delta}_{W L S}$,

$$
\widehat{\delta}_{W L S}=\left(\sum_{s=1}^{S} \widetilde{W_{s}} Z_{s}^{\prime} Z_{s}\right)^{-1} \sum_{s=1}^{S} \widetilde{W_{s}} Z_{s}^{\prime} \ln w_{s}=\left(\sum_{s=1}^{S} \widetilde{W_{s}} Z_{s}^{\prime} Z_{s}\right)^{-1} \sum_{s=1}^{S} \widetilde{W_{s}} Z_{s}^{\prime} Z_{s} \widehat{\delta}_{s},
$$

which is not consistent for the weighted average of the strata parameters $\delta$. Here, $\widetilde{W_{s}}=\left(\widetilde{n_{s}}\right)^{-1} n_{s}$, where $\widetilde{n_{s}}$ represents the sample values of strata-specific number of employees, $Z_{s}$ is the data matrix for stratum $s$ conformable to the definition of $\delta$ given above, and $\ln w_{s}$ is the column vector of $\ln w_{i j}$ for $i, j \in s .{ }^{19}$ Note that the WLS regression weights the strata-specific coefficient $\widehat{\delta}_{s}$ not only by $\widetilde{W_{s}}$, but also by matrix weights $Z_{s}^{\prime} Z_{s}$ corresponding to the precision of $\widehat{\delta}_{s} \cdot{ }^{20}$ The WLS estimator is consistent for $\delta$ if the parameter variation across strata is independent of the moment matrices and if the number of strata is large (see, e.g., Deaton, 1997, p. 70).

Due to the ISAE sampling procedure, each ISAE strata can be thought of as an independent survey, but the extent of sampling across strata (and the precision of each $\widehat{\delta}_{s}$ ) is not well defined. Further, Pesaran et al. (in press) note that neglecting coefficient heterogeneity can result in significant estimates of incorrectly included regressors and bias other parameters even if the erroneously included variables are orthogonal to the true regressors. One may therefore be interested in testing for the presence of parameter heterogeneity. Such tests are based on comparing $\widehat{\delta}_{W L S}$ with $\widehat{\delta}_{O L S}$ estimated off pooled unweighted data. Both estimators will be consistent in the absence of heterogeneity, but they will differ if parameters vary across strata. A version of the test based on Hausman (1978) can be conducted by running an auxiliary regression,

$$
\ln w_{s}=Z_{s} \theta+\widetilde{W_{s}} Z_{s} \lambda+v, \text { with } s=1, \ldots, S,
$$

\footnotetext{
${ }^{19}$ To see the inconsistency, assume that the strata proportions are held fixed as the sample size grows. Then

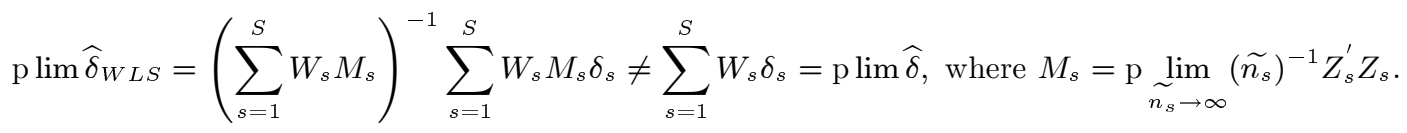

${ }^{20}$ Precision matrix weights are implicitly used by OLS and GLS, including, e.g., the random coefficients model.
} 
and testing the null hypothesis $H_{0}: \lambda=0$. (With hundreds of thousands of data points, it is very likely that any hypothesis will be rejected.)

In the subsequent analysis, I present two types of regression estimates. The first is based on a WLS regression estimated using pooled data from all strata. The second is based on equation 5 , which I refer to as split-sample weighting. The calculation of standard errors for both sets of results allows for any form of unconditional heteroscedasticity as well as interdependence of error terms within firms. This is important because person specific error terms will not be independent within firms in matched employer-employee data such as the ISAE. To capture this firm-level clustering I use a panel data version of the Huber/White estimator:

$$
\widehat{V}\left(\widehat{\delta}_{s}\right)=\left(Z_{s}^{\prime} Z_{s}\right)^{-1}\left(\sum_{j \in s} Z_{s j}^{\prime} \widehat{\epsilon}_{s j} \hat{\epsilon}_{s j}^{\prime} Z_{s j}\right)\left(Z_{s}^{\prime} Z_{s}\right)^{-1},
$$

where $\widehat{\epsilon}_{s j}=\ln w_{s j}-Z_{s j} \widehat{\delta}_{s}$ is the column vector of estimated error terms for employees of the $j$ th establishment in stratum $s$. (The subscript $s$ is dropped when calculating the WLS variance covariance matrix.)

\section{Results}

The simplest comparison of male and female wages conditions on only one explanatory characteristic at a time. Table 1 offers such comparison, based on weighted data in each country and sector. Each table entry is a percentage mean-wage disadvantage of women for a particular worker or firm category. There appears to be a lower mean gender wage gap for workers with only primary education (representing 8 to 9 years of schooling), except for the Slovak public sector, where relatively little data is included in the sample. Further, higher age seems to imply larger gender pay differentials, especially for workers below 50 years of age. This initial increase in the gap with age may be caused by maternity leaves on the part of women. The overall gap is smallest for employees of co-operatives in both countries and higher in all ownership categories in the Czech Republic compared to Slovakia. There does not appear to be a strong pattern with respect to firm size, except perhaps for the presence of somewhat lower pay gaps in smaller firms. 
While these results may be interesting, they do not provide enough guidance for policy purposes since they do not point to the sources of the gender pay differences. One of these potential sources is gender segregation, which is measured in this paper by the fraction of females in a particular occupation, firm, or job cell (defined as a group of workers with the same occupation within a firm). Further, to capture the extent to which women are employed as supervisors, the fraction of females among each firms' supervisory workforce is also calculated. (This statistic is of additional interest as female supervisors may be able to lower the overall pay gap within the firms they work for.) The mean values of the fraction-female statistics are reported in appendix Tables A-3 and A-4. ${ }^{21}$ A striking pattern immediately stands out: the public sector employs more than 3 times as many women as men in both countries. While there are more men than women working in the non-public sector, the ratio is not as dramatic. Consequently, there appears to be more segregation (a higher fraction of females by occupation, firm, or job cell) in the public sectors than in non-budgetary employment. Comparing the two countries, the extent of segregation is somewhat higher in the Czech Republic in both sectors.

A detailed picture of gender employment segregation is offered in Figures 1 to 3, where the weighted-sample distribution of the fraction-female statistics is plotted. Figure 1 compares the distribution of the fraction of female employment in 27 2-digit occupations across sectors and countries. The overall pattern is remarkably similar in the two economies. In the public sectors, very few workers are employed in occupations where less than a half of the employees are women. In the non-public sectors, the distribution of "femaleness" of occupations is relatively uniform. This is in stark contrast to a hypothetical segregation-free distribution. If the sample workers were assigned randomly to occupations (and sectors), the distribution would collapse around the total fraction female in the sample, which is about $45 \%$ in both countries after weighting and combining the two

\footnotetext{
${ }^{21}$ In the Czech Republic, I was also able to form an occupational segregation measure using the 1996 Microcensus dataset, which is a household survey conducted by the Czech Statistical Office every four years. It includes 12 thousand employed women and 13 thousand employed men, for whom the mean values of the fraction female in 2-digit occupation in 1996 are 0.648 and 0.330 respectively, quite comparable to the ISAE statistics for 1998.
} 
sectors.

The distribution of segregation of men and women into different firms is captured in Figure 2. Again, the two countries appear very similar with respect to this measure of workplace segregation, although in the public sector, the Czech distribution is more skewed toward 'female' firms. Again, given the large average firm size in the sample, random assignment of workers to these firms would results in almost all workers being employed in firms where $45 \%$ of employees are women.

Job-cell segregation appears to be quite intense in Figure 3, in that about a third of public-sector workers in both countries works in job cells where almost all employees are women. Furthermore, despite the relatively uniform distribution of occupational segregation in the non-public sectors, large spikes appears in the non-public job-cell distributions as about $25 \%$ of workers are employed in almost fully 'male' job cells. These spikes are preserved when only job cells with 10 or more workers are used in generating the distributions since less then $10 \%$ of workers in the Slovak data and about $3 \%$ of Czech-sample employees work in such small job cells. ${ }^{22}$ Superimposed on the histograms of job-cell segregation are simulated distributions based on random assignment of sample workers to job cells. ${ }^{23}$ The comparison to these segregation-free distributions points to significant gender segmentation of job cells.

The fraction-female measures will later be used to account for a part of the overall gender pay gap. But first, I will explore the standard human capital explanations, as well as sources of the pay differences, that are linked to firm characteristics. The simple wage comparisons presented in Table 1 fail to point to the source of the female/male wage gap. The subsequent analysis will therefore be based on logarithmic wage regressions, gradually expanding the set of explanatory variables. Table 2 presents the estimates of the female dummy from a sequence of specifications. In column (1), the female dummy estimate is reported based on a regression where no other explanatory variables

\footnotetext{
${ }^{22}$ Recall that the Slovak data consists of a random one-in-three subsample of workers from participating firms.

${ }^{23}$ These distributions are simulated by taking the sexes' overall sample shares and the sample size distribution of job cells as given. Unlike in the case of firm and occupational segregation, the job-cell distributions do not nearly collapse on the fraction of women in the sample. This is caused by the smaller number of workers per job cell.
} 
are used. This overall, unweighted logarithmic wage gap is about 0.28 in both sectors of the Czech economy. This is surprising in light of the dramatic difference in the female fraction of employment in each sector, and suggests that the primary cause of the Czech wage gap does not have to do with the division of labor between the budgetary and entrepreneurial sectors. The unadjusted unweighted gap is smaller in Slovakia: 0.18 in the public sector and about 0.24 elsewhere.

Results based on the split-sample weighting procedure (see Section 4) are presented in column (2). The Hausman-type test for presence of important parameter heterogeneity across strata (based on equation 7 and using estimates of the covariance matrix from equation ??) signals the need for weighting in every estimated specification. ${ }^{24}$ Weighting lowers all of the female dummy coefficients, with the largest decrease in the Czech public sector.

The next question is how much of the logarithmic wage gap (represented by the female dummy) can be accounted for by gender differences in workers' productive characteristics? In column (3), I therefore condition on workers' age and education. This reduces the unweighted estimate of the Czech public-sector female dummy by about 8 percentage points as women are more likely to have secondary education, while the fraction of college educated is higher for men (see Table A-3 for more details and recall that the wage grids used in the budgetary sector cement the dependence of wages on education). In Slovakia's public sector, the reduction in the female dummy estimate is even more pronounced and results in a strikingly low coefficient. The parameter estimate drops from about 0.18 to less than 0.8 when human capital characteristics are taken into account. This is again due to an unevenly high fraction of college educated male public employees. In contrast, the wage gap is actually increased by conditioning on human capital characteristics in both the Czech and Slovak non-budgetary sectors, as the overall distribution of education degrees is mildly favorable for women. (A similar result was obtained by Ogloblin, 1999.) The changes in weighted coefficients between columns (2) and (4) mirror the pattern of the unweighted estimates.

Ogloblin (1999) suggests that most of the Russian gender pay gap can be explained by condi-

\footnotetext{
${ }^{24}$ The test is highly statistically significant in every specification and sector; therefore, I do not report the test values. They are available upon request.
} 
tioning on industrial and ownership dummies, as well as on the extent of segregation by occupation. Columns (5) and (6) of Table 2 report specifications exploring the first half of his hypothesis for the Czech and Slovak Republics. It appears that controlling for a quadratic in firm size (employment) as well as for a set of dummy variables reflecting 2-digit industrial classification, ownership type, and geographical location of the firm or its establishment does not take away most of the female dummy estimate. In both of the Czech sectors, and in the Slovak non-public economy, the reduction in the unweighted female dummy is about 4 to 5 percentage points, and the decrease in estimates is even smaller when weighting is applied in column (6).

Further evidence on how much of the gender wage gap is due to between- as opposed to withinestablishment components is presented in columns (7) and (8) of Table 2. This specification includes not only worker-specific productive characteristics, but also a set of firm fixed effects. ${ }^{25}$ The female dummy estimates change little. It appears that the firm-level controls used in the previous columns captured most of the firms' impact on gender pay differences in all four sectors. In summary, employer identity plays a secondary but still an important role in the determination of the gender pay gap in both countries.

The first two columns of Table 3 explore the extent to which occupational segregation drives the gender wage differences by conditioning on the percent of female employment within 2-digit occupational classification as well as on all workers' and firms' characteristics. Occupational segregation in all cases except for the Slovak public sector significantly lowers both female and male wages in occupations, where a larger fraction of women is employed. The female dummy coefficient is reduced as a result of introducing the occupational segregation measure, but the decrease is relatively small compared to columns (7) and (8) of Table 2, especially in the weighted specifications. The Czech and Slovak estimates therefore suggest that occupational segregation is not the primary source of wage differences between men and women in Central European transition economies, in stark contrast to Ogloblin's (1999) analysis of Russian wages.

\footnotetext{
${ }^{25}$ See Carrington and Troske (1998) for a similar analysis conducted for U.S. manufacturing, where a large portion of the wage gap can be explained by controlling for employer identity.
} 
Columns (3) and (4) of Table 3 ask whether occupational segregation affects wages across firms or within firms. The newly introduced regressor captures the percent of female employment within narrowly defined job cells. The regression estimates suggest that job cell segregation is at least as important as occupational segregation as it further lowers the female dummy coefficient estimate and in most cases drives the occupational coefficient out of statistical significance.

The ISAE samples cover 27 2-digit occupations in both countries, while at the 4-digit level, there are 541 occupations in the Czech data and 497 in the Slovak sample. The choice of 2-digit occupational classification for capturing segregation is relatively arbitrary. In particular, segregation measures based on a more detailed classification suggest more segregation (see Tables A-3 and A4). Columns (5) and (6) therefore offer a direct comparison to columns (3) and (4) by estimating the same specification, but using a 4-digit occupational classification for calculating segregation measures. Even though some of the coefficients change, the qualitative results remain unaffected; therefore, I proceed with the 2-digit classification.

The richest specification is presented in column (7), where a firm-level segregation measure is added to the list of covariates, together with the fraction of females among each firm's supervisory workers. ${ }^{26}$ In the Czech Republic, the female dummy and the job-cell segregation coefficient are statistically significant at the $1 \%$ level and the firm-level segregation parameter is marginally significant in the non-public sector. In the Slovak public sector, both the negative effect of job cell segregation and the positive coefficient of the female fraction of supervisory workforce are marginally significant. The effect of firm-level segregation is large and precisely estimated in the Slovak non-public sector, as is the occupational segregation coefficient. Further, in the Czech public sector, about one third of the original female dummy coefficient from column (1) of Table 2 remains after I condition on all forms of segregation as well as on all other available explanatory characteristics. This 'unexplained' fraction reaches about two thirds in both the Czech and Slovak non-public sectors, suggesting that

\footnotetext{
${ }^{26}$ No supervisory workforce was reported for a fraction of firms and these firms were omitted from the subsequent analysis. This lack of data on supervisors may be a result of firms not reporting supervisory workforce together with top management or miscoding the occupational classification.
} 
potential violations of the equal pay provision are much more important outside of the budgetary sectors. In Slovakia's public sector, the female dummy estimate of column (7) is less than one quarter of the total pay gap, suggesting very little scope for gender pay discrimination. Unfortunately, the ISAE data does not provide full coverage of the Slovak public sector, so this result, while interesting, should be given less weight in terms of policy implications than the estimates from the other three sectors.

Some of the split-sample weighted estimates presented in column (8) are unstable when compared to column (7). This is so because the fraction of females as well as the fraction of female supervisors in a firm only vary across firms, while the number of firms within strata is often small (see Tables A-1 and A-2). The split-sample weighted estimates are constructed from strata-specific regressions and one coefficient outlier based on a small number of firms can dominate the averaged result. The female dummy estimates, however, remain fully unaffected and confirm the conclusions given in the preceding paragraph.

Similar to the data used by Ogloblin (1999) in Russia, the Czech and Slovak ISAE surveys do not include information on actual length of labor market experience and/or the number of children. It is therefore impossible to accurately capture the different labor market experience of men and women $^{27}$ and to control for important productivity-related characteristics. This is most likely to bias the female dummy coefficient upward. Maternity-related gender differences in labor market experience can be expected to be smallest for both older cohorts of workers, where the effect of previous labor market interruptions may be already wiped out, and younger cohorts, which have had relatively few leaves from the labor market. ${ }^{28}$ To the extent that these gender differences are presumably lower in the younger and older cohorts, I attempt to minimize the maternity-related

\footnotetext{
${ }^{27}$ Women in the Czech and Slovak Republics rely on an extensive public system of child-care, generous family allowances, and guaranteed maternity leaves of up to 3 years.

${ }^{28}$ During transition, young women became more likely to substitute careers for early motherhood. Between 1993 and 1997, the number of children born per 1000 women aged 20-24 decreased from 145.6 to 85.5 in the Czech Republic and from 166.7 to 106.2 in Slovakia (Charles University, 1999; Slovak Statistical Office, 1998).
} 
bias by separately estimating the preferred specification (column 7 of Table 3 ) for workers aged over 40 and under 25. There results are presented in columns (9) to (12) of Table 3. The female dummy estimates based on the older cohort remain fully comparable to the overall results (with the exception of the Slovak public sector). The results for the younger cohort, however, offer a very different picture, especially in the non-public sectors, where the scope for equal pay act violations becomes much smaller. There are two potential explanations for these results. Younger women may be paid relatively more equally to men as a result of having had fewer labor market interruptions. Alternatively, their career paths and remuneration practices may differ fundamentally from those of older women who had spent most of their working life under communism. The second explanation is particularly interesting and deserves further attention in future research.

In Slovakia, only a random one-in-three subsample of workers from surveyed firms was used in the analysis. This implies that the segregation measures, especially those related to individual firms, may be measured with error (see Bayard et al., 1999). Therefore, I also compare the female dummy coefficient from the preferred specification of column (7) of Table 3 to its estimate from a job-cell fixed effect specification from columns (9) to (10) of Table 2. Job cell fixed effects absorb all industry, occupation, and firm effects and account for any form of segregation in a fully unrestricted fashion. The female dummy estimates from the job-cell fixed effect specifications are only somewhat larger, suggesting a minor effect of measurement error.

These sensitivity tests do not reject column (7) of Table 3 as a preferred specification; therefore, I use it in all four sectors to calculate a mean wage decomposition. Table 4 reports the decomposition results based on equation 2 for the Czech public sector. The first column lists the unadjusted unweighted overall pay gap from the first column of Table 2, while column (2) of Table 4 reports most of the parameter estimates from the specification reported in column (7) of Table 3. About a third of the overall gender wage gap is due to gender differences in wages that remain after controlling for all available explanatory characteristics. Another third is explained by the segregation of women into low-paying occupations and job cells. Finally, the last third of the pay gap is attributable to 
uneven distribution of education among men and women in the Czech budgetary sector. Specifically, men are much more likely to have university education than women.

As mentioned earlier, the picture is dramatically different in both the Czech and Slovak nonpublic sector (see Tables 5 and 7). Here, almost two thirds of the overall pay gap remain unexplained by other factors and the potential scope for gender pay discrimination appears high. If all of this female dummy estimate was due to discrimination, female wages would be raised by about one fifth by full compliance with the equal pay act. A substantial part of this unexplained gap is, however, likely to be due to maternity-related differences in labor market experience of men and women, which none of the estimated regressions controls for.

Similar to the results for the Czech public sector, the decompositions in Table 5 and 7 suggest that employment segregation is related to over one third of the total gender pay gap in Czech and Slovak non-public employment. The channels of the effect are different, though, between the two countries. While in both Czech sectors, it is the occupational and job cell segregation that drives the pay wedge between genders, firm-level segregation is equally important in the Slovak non-public sector. The wage impacts of gender differences in educational attainment average out across the different degrees to a negligible effect. Other worker- or firm-specific characteristics also attribute little to the mean wage difference between genders.

The overall gender pay difference, as well as the potential extent of pay discrimination are lowest in the Slovak public sector - see Table 6, which also documents the relatively small effect of segregation on the female dummy estimate. The largest part of the gap is attributable to a higher fraction of male college-educated public employees. Even though the coefficient on the female fraction among the firm's supervisory workforce is (marginally) significant, its effect on the mean wage gap is small. Unfortunately, the Slovak public-sector results are based on a relatively small sample and in particular say little about gender pay differences in Slovakia's public administration. 


\section{Conclusion}

This paper identifies the channels through which gender segregation and an individual's sex affect the overall gender wage gap in the Czech and Slovak Republics. These countries, similar to other transition economies aiming at joining the EU, are now in the process of enacting standard westernstyle anti-discrimination labor market policies. The empirical results presented here provide a measure of the potential efficacy of these policies in reducing the overall gender pay differential. By capturing the situation immediately before the anti-discrimination rules are legally enacted, ${ }^{29}$ the present analysis also serves as a detailed benchmark for future measurement of the actual effect of the anti-discrimination efforts in transition countries. Pre-accession countries will provide a laboratory where anti-discrimination laws are introduced at a relatively high level of development and where rich micro data will often be available to observe the impact of all of these policies in detail.

On average, female wages are about $30 \%$ lower than male wages in both countries, and this difference is somewhat lower in the budgetary sectors. Even though wages are typically lower in the public sectors, which employ over three times as many women as men, this imbalance is not the primary cause of the overall gender pay gap. Segregation of women into low-paying occupations, firms and job cells appears responsible for about one third of the total wage gap. Furthermore, in the non-public sectors of the Czech and Slovak Republics, about two thirds of the wage gap appear due to gender differences in wages that remain after accounting for most forms of workplace segregation as well as for other explanatory variables. This compares unfavorably to about one third in the U.S., where the overall gap is, however, larger at over 40\% (Bayard et al., 1999).

Unfortunately, the estimated 'pure' wage effect of the individual's sex is likely to be biased upward due to lack of information in the Czech and Slovak data on the actual length of labor

\footnotetext{
${ }^{29}$ The discussed amendments of the Czech Labor Code and Wage Law were approved by the Czech government in 1999. Their legal enactment is expected during the year 2000. In Slovakia, a similar amendment in now in the final stage of preparations at the Ministry of Labor, Social Affairs and Family.
} 
market experience and/or the number of children. The estimated female dummy coefficients for the youngest cohort are indeed lower than the all-sample estimate and resemble the U.S. coefficients. Finally, a substantial part of the gender pay gap is attributable to differences in educational attainment of men and women in the Czech and Slovak public sectors, where hiring and promotion practices should be particularly easy to affect.

The gender wage gap is generally lower in Slovakia and the scope for pay discrimination appears especially low in the Slovak public sector. This difference between the two economies that until recently formed one country calls for future research. It may be a consequence of the faster freemarket transformation of the Czech economy, where wage setting may have departed farther from the communist wage grid.

The policy implications of these results are different from those that Ogloblin (1999) presents for Russia. ${ }^{30}$ In the Czech and Slovak Republics, it is not occupational segregation that is to blame for most of the gender wage gap, but rather within-occupation within-establishment phenomena. This implies a different strategy for reducing the gender pay gap. Attention should not be paid primarily to differences in remuneration across occupations (comparable worth policies), but rather to potential within-establishment pay discrimination, especially violations of the equal pay clause.

The empirical results of this paper are descriptive in their nature. They identify the channels, by which segregation affects gender wage differences, but not the fundamental causes of segregation. One interpretation of the effect segregation has on wages is employer discrimination in hiring and promotion. Another is suggested by Macpherson and Hirsh (1995) who account for most of the wage effect of occupational gender segregation in the U.S. by conditioning on skill-related occupational characteristics and unmeasured skill or taste differences of workers. They imply that the relative proportion of female employment in an occupation reflects these characteristics and taste differences and should not be of major policy concern. However, as argued in Ogloblin (1999) and as I have

\footnotetext{
${ }^{30}$ This seems due to differences in underlying gender wage structures of the two regions, rather than to the lack of information on job cell and firm segregation in Ogloblin's data.
} 
argued in Section 2 of this paper, occupational segregation under central planning was to a large extent the result of communist policies treating women as "specific labor force" and institutionalizing gender segregation. Much of this legacy of communism remains visible in today's transition labor markets. ${ }^{31}$ It is unlikely that central planners understood and reflected the fundamental taste differences and unmeasured skills of their workers; therefore, occupational segregation in transition countries is relatively unlikely to be driven mainly by unobservables.

\footnotetext{
${ }^{31}$ E.g., the overwhelming fraction of female employees in the budgetary sector. Further, the fraction of workers employed in each major occupation group as well as the fraction of women within each of these groups was almost constant between 1993 and 1998, when measured using the earliest and latest available wave of the Czech Labor Force Survey. These results are available upon request.
} 


\section{Bibliography}

Abowd, J.M. and F. Kramarz (in press) "The Analysis of labor Markets using Matched Employer-Employee Data," in Ashenfelter, O., and D. Card, eds. Handbook of Labor Economics, volumes 3-4, Amsterdam, North Holland.

Pesaran, M.H., and Haque, N.U., and S. Sharma (in press) "Neglected Heterogeneity and Dynamics in Cross-country Savings Regressions," in Krishnakumar, J., and E. Ronchetti, eds. Panel Data Econometrics - Future Direction: Papers in Honor of Professor Balestra, Contributions to Economic Analysis, Elsevier Science.

Altonji, J.G., and R.M. Blank (in press) "Race and Gender in the Labor Market," in Ashenfelter, O., and D. Card, eds. Handbook of Labor Economics, volumes 3-4, Amsterdam, North Holland.

Bayard, K., Hellerstein, J., Neumark D. and K. Troske (1999) "New Evidence on Sex Segregation and Sex Differences in Wages from Matched Employee-Employer Data," NBER Working Paper No. 7003.

Bielby, W. and J. Baron (1984) "A Woman's Place is with Other Women: Sex Segregation Within Organizations," in B. Redskin, ed., Sex Segregation in the Workplace: Trends, Explanations, Remedies, Washington, DC, National Academy Press, pp. 37-55.

Blau, F.D. (1977) Equal Pay in the Office, Lexington, MA, D.C. Health and Company.

Brainerd, E. (1998) "Winners and Losers in Russias Economic Transition," American Economic Review, 88(5), 1094-1116.

Carrington, W.J. and K.R. Troske (1998) "Sex Segregation in U.S. Manufacturing," Industrial and Labor Relations Review, 51 (3), 445-464.

Chase, R.S. (1998) "Markets for Communist Human Capital: Returns to Education and Experience in PostCommunist Czech Republic and Slovakia," Industrial and Labor Relations Review, 51 (3), 401-423.

Charles University, Faculty of Science, Department of Demography (1999) Population Development in the Czech Republic, Prague: Charles University Press.

Deaton, A. (1997) The Analysis of Household Surveys, Baltimore and London: Johns Hopkins University Press.

Filer, R., Jurajda Š., and J. Plánovský (1999) "Education and Wages in the Czech and Slovak Republics during Transition," Labour Economics, 6 (4), 581-593.

Groshen, E.L. (1991) "The Structure of the Female/Male Wage Differential: Is it Who You Are, What You Do, or Where You Work?," Journal of Human Resources, 26 (3), 457-72.

Ham, J., Svejnar, J., and K. Terrell (1995) "Czech Republic and Slovakia," in Commander, S., and F. Coricelli, eds. Unemployment, Restructuring, and the Labor Market in Eastern Europe and Russia, Economic Development Institute of the World Bank, Washington, D.C. 
Ham, J., Svejnar, J., and K. Terrell (1999) "Women's Unemployment During Transition: Evidence from Czech and Slovak Micro-data," Economics of Transition, 7 (1), 47-78.

Hunt, J. (1998) "The Transition in East Germany: When is a Ten Per Cent Fall in the Gender Pay Gap Bad News," CEPR Discussion Paper Series in Transition Economics, No. 1,805.

Jackman, R., and M. Rutkowski (1994) "Labor Markets: Wages and Employment" in Barr, N. , ed., Labor Markets and Social Policy in Central and Eastern Europe, Oxford University Press, New York.

Johnson, G., and G. Solon (1986) "Estimates of the Direct Effect of Comparable Worth Policy," American Economic Review, 26(2), 287-307.

Killingsworth, M. (1990) The Economics of Comparable Worth, Kalamazoo, Mich.: W. E. Upjohn Institute for Employment Research.

Macpherson, D., and B.T. Hirsh (1995) "Wages and Gender Composition: Why Do Women's Jobs Pay Less," Journal of Labor Economics, 13, 426-471.

Münich, D., J. Svejnar, and K. Terrell (1999) "Returns to human capital under the communist wage grid and during the transition to a market economy," Discussion Paper No. 29, CERGE-EI, Prague, 1998.

Newell, A., and B. Reilly (1996) "The Gender Wage Gap in Russia: Some Empirical Evidence," Labour Economics, $3,337-356$.

Oaxaca, R. (1973) "Male-Female Wage Differentials in Urban Labor Markets", International Economic Review, 14(3), 693-709.

Oaxaca, R. and M.R. Ransom (1994) "On Discrimination and the Decomposition of Wage Differentials", Journal of Econometrics, 61, 5-21.

Ogloblin, C.G. (1999) "The Gender Earnings Differential in the Russian Transition Economy," Industrial and Labor Relations Review, 52(4), 602-27.

Orazem, P.F., and M. Vodopivec (1995) "Winners and Losers in Transition: Returns to Education, Experience, and Gender in Slovenia," The World Bank Economic Review, 9(2), 201-230.

Paukert, L. (1991) "The Economic Status of Women in the Transition to a Market System: The Case of Czechoslovakia," International Labour Review, 130, 613-633.

Reilly, B. (1999) "The Gender pay Gap in Russia during Transition, 1992-1996," Economics of Transition, 7 (1): 245-264.

Slovak Statistical Office (1998) Statistical Yearbook 1998, Bratislava, Slovakia.

Svejnar, J. (in press) "Labor Markets in the Transitional Central and East European Economies," in Ashenfelter, O., and D. Card, eds. Handbook of Labor Economics, volumes 3-4, Amsterdam, North Holland. 
Table A-1: Czech ISAE Sample Description by Sampling Strata

Number of Employees in Sample, (Number of Firms in Sample), and \{Number of Firms in Population\}.

\begin{tabular}{|c|c|c|c|c|c|}
\hline Firm Employment & $100-249$ & $250-499$ & $500-999$ & over 1000 & Total \\
\hline \multirow[t]{3}{*}{ Agriculture, Forestry, and Fishing } & 2,820 & 1,597 & 763 & 6,820 & 12,000 \\
\hline & $(17)$ & $(5)$ & $(1)$ & (3) & $(26)$ \\
\hline & $\{116\}$ & $\{637\}$ & $\{124\}$ & $\{7\}$ & $\{884\}$ \\
\hline \multirow{3}{*}{ Mining, Quarrying, and Metalurgy } & 113 & 767 & 1,187 & 26,399 & 28,466 \\
\hline & $(1)$ & $(2)$ & (2) & $(5)$ & $(10)$ \\
\hline & $\{12\}$ & $\{56\}$ & $\{33\}$ & $\{27\}$ & $\{128\}$ \\
\hline \multirow[t]{3}{*}{ Food, Textile, and Leather } & 3,007 & 5,177 & 13,741 & 27,373 & 49,298 \\
\hline & $(17)$ & $(15)$ & (19) & (14) & $(65)$ \\
\hline & $\{77\}$ & $\{357\}$ & $\{146\}$ & $\{46\}$ & $\{626\}$ \\
\hline \multirow[t]{3}{*}{ Paper and Chemicals } & 3,571 & 7,977 & 20,383 & 75,621 & 107,552 \\
\hline & $(21)$ & $(22)$ & (29) & $(25)$ & (97) \\
\hline & $\{59\}$ & $\{243\}$ & $\{105\}$ & $\{45\}$ & $\{452\}$ \\
\hline \multirow[t]{3}{*}{ Machinery } & 5,140 & 11,812 & 25,231 & 59,799 & 101,982 \\
\hline & $(30)$ & $(31)$ & (34) & (32) & $(127)$ \\
\hline & $\{95\}$ & $\{523\}$ & $\{230\}$ & $\{92\}$ & $\{940\}$ \\
\hline \multirow[t]{3}{*}{ Utilities } & 1,081 & 1,467 & 6,936 & 29,453 & 38,937 \\
\hline & (6) & (4) & (10) & (13) & (33) \\
\hline & $\{11\}$ & $\{55\}$ & $\{28\}$ & $\{20\}$ & $\{114\}$ \\
\hline \multirow[t]{3}{*}{ Construction } & 1,544 & 6,775 & 7,443 & 17,970 & 33,732 \\
\hline & (11) & (18) & (11) & (8) & $(48)$ \\
\hline & $\{54\}$ & $\{320\}$ & $\{116\}$ & $\{16\}$ & $\{506\}$ \\
\hline Wholesale and Retail Trade, and Repair & 1,637 & 2,943 & 4,181 & 12,671 & 21,432 \\
\hline \multirow[t]{2}{*}{ Services } & $(10)$ & $(8)$ & $(6)$ & $(6)$ & $(30)$ \\
\hline & $\{40\}$ & $\{298\}$ & $\{111\}$ & $\{14\}$ & $\{463\}$ \\
\hline \multirow[t]{3}{*}{ Transportation and Communications } & 2,513 & 3,342 & 6,219 & 71,528 & 83,602 \\
\hline & $(18)$ & (9) & $(11)$ & $(10)$ & (48) \\
\hline & $\{22\}$ & $\{122\}$ & $\{50\}$ & $\{20\}$ & $\{214\}$ \\
\hline \multirow[t]{3}{*}{ Banking and Insurance } & 1,453 & 1,926 & 1,868 & 37,132 & 42,379 \\
\hline & $(9)$ & (6) & (3) & $(6)$ & $(24)$ \\
\hline & $\{9\}$ & $\{35\}$ & $\{8\}$ & $\{8\}$ & $\{60\}$ \\
\hline \multirow{3}{*}{$\begin{array}{l}\text { Real Estate, R\&D, Data Processing, and } \\
\text { other Business Activities }\end{array}$} & 3,308 & 1,951 & 3,260 & 4,355 & 12,874 \\
\hline & $(22)$ & $(6)$ & $(5)$ & $(2)$ & $(35)$ \\
\hline & $\{58\}$ & $\{264\}$ & $\{75\}$ & $\{8\}$ & $\{405\}$ \\
\hline \multirow[t]{3}{*}{ Public Administration, and Social Security } & 2,035 & 1,174 & 4,550 & 28,863 & 36,622 \\
\hline & $(12)$ & (3) & (6) & (7) & $(28)$ \\
\hline & $\{33\}$ & $\{134\}$ & $\{37\}$ & $\{16\}$ & $\{220\}$ \\
\hline \multirow[t]{3}{*}{ Education } & 136 & 306 & 4,200 & 87,281 & 91,923 \\
\hline & $(1)$ & (1) & $(5)$ & (4) & $(11)$ \\
\hline & $\{67\}$ & $\{8\}$ & $\{10\}$ & $\{6\}$ & $\{91\}$ \\
\hline \multirow[t]{3}{*}{ Health and Social Work } & 1,225 & 5,488 & 9,991 & 32,960 & 49,664 \\
\hline & $(7)$ & $(15)$ & $(14)$ & $(17)$ & $(53)$ \\
\hline & $\{36\}$ & $\{177\}$ & $\{90\}$ & $\{35\}$ & $\{338\}$ \\
\hline Hotels and Restaurants, Other Community, & 1,083 & 4,783 & 1,093 & 9,213 & 16,172 \\
\hline \multirow[t]{2}{*}{ Social, and Personal Service Activities } & $(7)$ & (14) & $(2)$ & $(5)$ & $(28)$ \\
\hline & $\{38\}$ & $\{210\}$ & $\{54\}$ & $\{8\}$ & $\{310\}$ \\
\hline \multirow[t]{3}{*}{ Total } & 30,666 & 57,440 & 111,046 & 527,438 & 726,590 \\
\hline & $(189)$ & $(159)$ & $(158)$ & (157) & (663) \\
\hline & $\{727\}$ & $\{3439\}$ & $\{1217\}$ & $\{368\}$ & $\{5751\}$ \\
\hline
\end{tabular}

Note: Boxed firms have been merged into a single strata to ensure presence of at least two firms per strata. 
Table A-2: Slovak ISAE Sample Description by Sampling Strata

Number of Employees in Sample*, (Number of Firms in Sample), and \{Number of Firms in Population\}.

\begin{tabular}{|c|c|c|c|c|}
\hline Firm Employment & \multicolumn{3}{|c|}{ Industry Category } & Total \\
\hline \multirow[t]{3}{*}{ Agriculture, Forestry, and Fishing } & 2,128 & 238 & 2,898 & 5,264 \\
\hline & $(24)$ & $(1)$ & (4) & $(29)$ \\
\hline & $\{457\}$ & $\{8\}$ & $\{8\}$ & $\{473\}$ \\
\hline \multirow[t]{3}{*}{ Mining, Quarrying, and Metalurgy } & 611 & 0 & 2,676 & 3,287 \\
\hline & $(7)$ & $(0)$ & $(1)$ & (8) \\
\hline & $\{22\}$ & $\{4\}$ & $\{10\}$ & $\{36\}$ \\
\hline \multirow[t]{3}{*}{ Food, Textile, and Leather } & 2,803 & 1,619 & 6,510 & 10,932 \\
\hline & $(33)$ & (7) & $(10)$ & $(50)$ \\
\hline & $\{313\}$ & $\{43\}$ & $\{15\}$ & $\{371\}$ \\
\hline \multirow[t]{3}{*}{ Paper and Chemicals } & 2,274 & 2,949 & 15,961 & 21,184 \\
\hline & $(25)$ & (11) & $(20)$ & $(56)$ \\
\hline & $\{187\}$ & $\{22\}$ & $\{34\}$ & $\{243\}$ \\
\hline \multirow[t]{3}{*}{ Machinery } & 3,358 & 1,736 & 10,518 & 15,612 \\
\hline & $(41)$ & (8) & $(15)$ & $(64)$ \\
\hline & $\{387\}$ & $\{52\}$ & $\{35\}$ & $\{474\}$ \\
\hline \multirow[t]{3}{*}{ Utilities } & 3,066 & 179 & 3,984 & 7,229 \\
\hline & $(42)$ & (1) & $(5)$ & $(48)$ \\
\hline & $\{25\}$ & $\{5\}$ & $\{14\}$ & $\{44\}$ \\
\hline \multirow[t]{3}{*}{ Construction } & 1,510 & 0 & 2,916 & 4,426 \\
\hline & $(20)$ & $(0)$ & (4) & $(24)$ \\
\hline & $\{221\}$ & $\{5\}$ & $\{12\}$ & $\{238\}$ \\
\hline Wholesale and Retail Trade, and Repair & 1,818 & 242 & 426 & 2,486 \\
\hline \multirow[t]{2}{*}{ Services } & $(21)$ & $(1)$ & $(1)$ & $(23)$ \\
\hline & $\{251\}$ & $\{18\}$ & $\{4\}$ & $\{273\}$ \\
\hline \multirow[t]{3}{*}{ Transportation and Communications } & 3,572 & 1,980 & 18,281 & 23,833 \\
\hline & $(43)$ & (9) & $(12)$ & $(64)$ \\
\hline & $\{115\}$ & $\{9\}$ & $\{15\}$ & $\{139\}$ \\
\hline \multirow[t]{3}{*}{ Banking and Insurance } & 461 & 1,517 & 0 & 1,978 \\
\hline & $(5)$ & $(5)$ & $(0)$ & $(10)$ \\
\hline & $\{29\}$ & $\{6\}$ & $\{5\}$ & $\{40\}$ \\
\hline \multirow{3}{*}{$\begin{array}{l}\text { Real Estate, R\&D, Data Processing, and } \\
\text { other Business Activities }\end{array}$} & 1,117 & 208 & 0 & 1,325 \\
\hline & $(15)$ & $(1)$ & $(0)$ & $(16)$ \\
\hline & $\{197\}$ & $\{9\}$ & $\{2\}$ & $\{208\}$ \\
\hline \multirow[t]{3}{*}{ Public Administration, and Social Security } & 82 & 0 & 0 & 82 \\
\hline & $(2)$ & $(0)$ & $(0)$ & (2) \\
\hline & $\{128\}$ & $\{35\}$ & $\{42\}$ & $\{205\}$ \\
\hline \multirow[t]{3}{*}{ Education } & 306 & 463 & 6,025 & 6,794 \\
\hline & (4) & (2) & (9) & $(15)$ \\
\hline & $\{144\}$ & $\{22\}$ & $\{9\}$ & $\{175\}$ \\
\hline \multirow[t]{3}{*}{ Health and Social Work } & 323 & 836 & 5,674 & 6,833 \\
\hline & (4) & (4) & (10) & (18) \\
\hline & $\{136\}$ & $\{33\}$ & $\{33\}$ & $\{202\}$ \\
\hline \multirow{3}{*}{$\begin{array}{l}\text { Hotels and Restaurants, Other Community, } \\
\text { Social, and Personal Service Activities }\end{array}$} & 1,095 & 0 & 338 & 1,433 \\
\hline & $(15)$ & $(0)$ & $(1)$ & $(16)$ \\
\hline & $\{153\}$ & $\{8\}$ & $\{3\}$ & $\{164\}$ \\
\hline \multirow[t]{3}{*}{ Total } & 24,524 & 11,967 & 76,207 & 112,698 \\
\hline & $(301)$ & $(50)$ & $(92)$ & $(443)$ \\
\hline & $\{2765\}$ & $\{279\}$ & $\{241\}$ & $\{3285\}$ \\
\hline
\end{tabular}

*The data consists of a randomly drawn one-in-three sub-sample of employees from participating firms.

Note: Boxed firms have been merged into a single strata to ensure presence of at least two firms per strata. 
Table A-3: Means in Czech ISAE

\begin{tabular}{|c|c|c|c|c|c|}
\hline \multirow{2}{*}{\multicolumn{2}{|c|}{ Variable }} & \multicolumn{2}{|c|}{ ISAE unweighted } & \multicolumn{2}{|c|}{ ISAE weighted } \\
\hline & & Women & Men & Women & Men \\
\hline \multicolumn{6}{|c|}{ Public Sector } \\
\hline \multicolumn{2}{|c|}{ Hourly wage (CZK) } & 53.994 & 73.188 & 52.564 & 68.872 \\
\hline \multicolumn{2}{|c|}{$\%$ female in 2 -digit occupation } & 0.779 & 0.452 & 0.776 & 0.489 \\
\hline \multicolumn{2}{|c|}{$\%$ female in 4 -digit occupation } & 0.869 & 0.409 & 0.865 & 0.428 \\
\hline \multicolumn{2}{|c|}{$\%$ female in firm } & 0.839 & 0.594 & 0.826 & 0.636 \\
\hline \multicolumn{2}{|c|}{$\%$ female supervisors in firm } & 0.674 & 0.360 & 0.615 & 0.380 \\
\hline \multicolumn{2}{|c|}{$\%$ female in 2 -digit job cell } & 0.887 & 0.418 & 0.883 & 0.428 \\
\hline \multicolumn{2}{|c|}{$\%$ female in 4-digit job cell } & 0.900 & 0.370 & 0.896 & 0.379 \\
\hline \multicolumn{2}{|c|}{ Age } & 38.840 & 36.018 & 38.876 & 35.664 \\
\hline \multirow[t]{5}{*}{ Education } & Primary & 0.071 & 0.025 & 0.072 & 0.029 \\
\hline & Secondary without GCE & 0.175 & 0.184 & 0.169 & 0.206 \\
\hline & Secondary with GCE & 0.490 & 0.252 & 0.546 & 0.293 \\
\hline & University & 0.261 & 0.493 & 0.210 & 0.436 \\
\hline & Post-graduate & 0.003 & 0.046 & 0.003 & 0.037 \\
\hline \multicolumn{2}{|c|}{ Total employment in firm/1000 } & 44.3 & 27.6 & 29.4 & 18.1 \\
\hline \multicolumn{2}{|c|}{ Prague (capital) } & 0.198 & 0.543 & 0.169 & 0.400 \\
\hline \multirow{2}{*}{\multicolumn{2}{|c|}{$\begin{array}{l}\text { Number of workers } \\
\text { Number of firms }\end{array}$}} & 140,254 & 37,955 & 140,254 & 37,955 \\
\hline & & 92 & 92 & 92 & 92 \\
\hline \multicolumn{2}{|c|}{ Number of firms } & Public Sec & & & \\
\hline \multicolumn{2}{|c|}{ Hourly wage (CZK) } & 59.775 & 80.745 & 54.266 & 74.647 \\
\hline \multicolumn{2}{|c|}{$\%$ female in 2-digit occupation } & 0.629 & 0.278 & 0.623 & 0.294 \\
\hline \multicolumn{2}{|c|}{$\%$ female in 4-digit occupation } & 0.677 & 0.215 & 0.673 & 0.213 \\
\hline \multicolumn{2}{|c|}{$\%$ female in firm } & 0.531 & 0.301 & 0.540 & 0.304 \\
\hline \multicolumn{2}{|c|}{$\%$ female supervisors in firm } & 0.317 & 0.149 & 0.309 & 0.143 \\
\hline \multicolumn{2}{|c|}{$\%$ female in 2-digit job cell } & 0.695 & 0.196 & 0.707 & 0.194 \\
\hline \multicolumn{2}{|c|}{$\%$ female in 4-digit job cell } & 0.755 & 0.157 & 0.773 & 0.150 \\
\hline \multicolumn{2}{|l|}{ Age } & 38.551 & 38.809 & 38.096 & 38.265 \\
\hline Education & Primary & 0.103 & 0.048 & 0.108 & 0.059 \\
\hline & Secondary without GCE & 0.403 & 0.580 & 0.465 & 0.604 \\
\hline & Secondary with GCE & 0.388 & 0.248 & 0.340 & 0.218 \\
\hline & University & 0.105 & 0.122 & 0.084 & 0.113 \\
\hline & Post-graduate & 0.001 & 0.002 & 0.002 & 0.006 \\
\hline Total empl & oyment in firm/1000 & 5.102 & 5.911 & 2.202 & 2.836 \\
\hline Prague (ca & pital) & 0.278 & 0.208 & 0.224 & 0.184 \\
\hline Ownership & Foreign & 0.062 & 0.048 & 0.036 & 0.028 \\
\hline & Private & 0.625 & 0.617 & 0.655 & 0.702 \\
\hline & Co-operative & 0.036 & 0.013 & 0.115 & 0.061 \\
\hline & State & 0.271 & 0.314 & 0.188 & 0.201 \\
\hline & Mixed & 0.006 & 0.008 & 0.005 & 0.008 \\
\hline Number of & workers & 214,277 & 334,104 & 214,277 & 334,104 \\
\hline Number of & firms & 571 & 571 & 571 & 571 \\
\hline
\end{tabular}


Table A-4: Means in Slovak ISAE

\begin{tabular}{|c|c|c|c|c|c|}
\hline \multirow{2}{*}{\multicolumn{2}{|c|}{ Variable }} & \multicolumn{2}{|c|}{ ISAE unweighted } & \multicolumn{2}{|c|}{ ISAE weighted } \\
\hline & & Women & Men & Women & Men \\
\hline \multicolumn{6}{|c|}{ Public Sector } \\
\hline \multicolumn{2}{|c|}{ Hourly wage (SKK) } & 47.065 & 58.925 & 51.107 & 61.441 \\
\hline \multicolumn{2}{|c|}{$\%$ female in 2 -digit occupation } & 0.660 & 0.498 & 0.664 & 0.497 \\
\hline \multicolumn{2}{|c|}{$\%$ female in 4 -digit occupation } & 0.784 & 0.473 & 0.797 & 0.463 \\
\hline \multicolumn{2}{|c|}{$\%$ female in firm } & 0.788 & 0.706 & 0.795 & 0.712 \\
\hline \multicolumn{2}{|c|}{$\%$ female supervisors in firm } & 0.708 & 0.603 & 0.696 & 0.608 \\
\hline \multicolumn{2}{|c|}{$\%$ female in 2 -digit job cell } & 0.851 & 0.496 & 0.865 & 0.469 \\
\hline \multicolumn{2}{|c|}{$\%$ female in 4-digit job cell } & 0.867 & 0.444 & 0.884 & 0.405 \\
\hline \multicolumn{2}{|c|}{ Age } & 39.632 & 43.557 & 39.976 & 43.549 \\
\hline \multirow[t]{5}{*}{ Education } & Primary & 0.119 & 0.056 & 0.107 & 0.052 \\
\hline & Secondary without GCE & 0.230 & 0.302 & 0.215 & 0.324 \\
\hline & Secondary with GCE & 0.470 & 0.201 & 0.519 & 0.215 \\
\hline & University & 0.163 & 0.319 & 0.145 & 0.275 \\
\hline & Post-graduate & 0.018 & 0.122 & 0.013 & 0.134 \\
\hline \multicolumn{2}{|c|}{ Total employment in firm/1000 } & 1.840 & 2.147 & 0.924 & 0.965 \\
\hline \multicolumn{2}{|c|}{ Bratislava (capital) } & 0.190 & 0.290 & 0.150 & 0.250 \\
\hline \multirow{2}{*}{\multicolumn{2}{|c|}{$\begin{array}{l}\text { Number of workers } \\
\text { Number of firms }\end{array}$}} & 10,543 & 3,166 & 10,543 & 3,166 \\
\hline & & 35 & 35 & 35 & 35 \\
\hline \multicolumn{2}{|c|}{ Number of firms } & ublic Sec & & & \\
\hline \multicolumn{2}{|c|}{ Hourly wage (SKK) } & 55.331 & 71.177 & 52.111 & 66.273 \\
\hline \multicolumn{2}{|c|}{$\%$ female in 2-digit occupation } & 0.558 & 0.280 & 0.567 & 0.315 \\
\hline \multicolumn{2}{|c|}{$\%$ female in 4-digit occupation } & 0.631 & 0.221 & 0.628 & 0.245 \\
\hline \multicolumn{2}{|c|}{$\%$ female in firm } & 0.506 & 0.293 & 0.512 & 0.301 \\
\hline \multicolumn{2}{|c|}{$\%$ female supervisors in firm } & 0.394 & 0.240 & 0.415 & 0.261 \\
\hline \multicolumn{2}{|c|}{$\%$ female in 2-digit job cell } & 0.679 & 0.190 & 0.684 & 0.195 \\
\hline \multicolumn{2}{|c|}{$\%$ female in 4 -digit job cell } & 0.741 & 0.154 & 0.743 & 0.159 \\
\hline \multicolumn{2}{|l|}{ Age } & 38.443 & 38.922 & 38.206 & 38.889 \\
\hline Education & Primary & 0.165 & 0.088 & 0.170 & 0.094 \\
\hline & Secondary without GCE & 0.368 & 0.510 & 0.381 & 0.522 \\
\hline & Secondary with GCE & 0.403 & 0.326 & 0.382 & 0.292 \\
\hline & University & 0.063 & 0.074 & 0.066 & 0.089 \\
\hline & Post-graduate & 0.001 & 0.002 & 0.001 & 0.003 \\
\hline Total empl & oyment in firm/1000 & 2.458 & 3.403 & 1.289 & 1.910 \\
\hline Bratislava & (capital) & 0.147 & 0.144 & 0.174 & 0.137 \\
\hline Ownership & Foreign & 0.082 & 0.075 & 0.088 & 0.077 \\
\hline & Private & 0.365 & 0.348 & 0.421 & 0.421 \\
\hline & Co-operative & 0.029 & 0.015 & 0.090 & 0.060 \\
\hline & State & 0.453 & 0.475 & 0.334 & 0.340 \\
\hline & Mixed & 0.072 & 0.087 & 0.068 & 0.103 \\
\hline Number of & workers & 35,974 & 63,015 & 35,974 & 63,015 \\
\hline Number of & firms & 408 & 408 & 408 & 408 \\
\hline
\end{tabular}


Table A-5: Estimated Log Wage Differentials by Sex: Split-sample Weighting

\begin{tabular}{|c|c|c|c|c|c|c|}
\hline & (1) & (2) & (3) & (4) & (5) & (6) \\
\hline \multicolumn{7}{|c|}{ Czech Public Sector } \\
\hline$\overline{\text { Female }}$ & $\begin{array}{c}-0.208 * \\
(0.007)\end{array}$ & $\begin{array}{c}-0.150 * \\
(0.005)\end{array}$ & $\begin{array}{c}-0.147 * \\
(0.006)\end{array}$ & $\begin{array}{c}-0.100 * \\
(0.004)\end{array}$ & $\begin{array}{c}-0.120 * \\
(0.006)\end{array}$ & $\begin{array}{c}-0.101 * \\
(0.005)\end{array}$ \\
\hline$\%$ female in occupation & $\ldots$ & $\ldots$ & $\ldots$ & $\ldots$ & $\begin{array}{c}-0.181 * \\
(0.015)\end{array}$ & $\begin{array}{c}-0.124 * \\
(0.025)\end{array}$ \\
\hline$\%$ female in job cell & $\ldots$ & $\ldots$ & $\ldots$ & $\ldots$ & $\ldots$ & $\begin{array}{r}-0.112 * \\
(0.024)\end{array}$ \\
\hline Number of workers & 178,209 & 178,209 & 178,209 & 163,072 & 178,209 & 178,209 \\
\hline Number of firms & 92 & 92 & 92 & $913^{\mathrm{b}}$ & 92 & 92 \\
\hline \multicolumn{7}{|c|}{ Czech Non-Public Sector } \\
\hline$\overline{\text { Female }}$ & $\begin{array}{c}-0.269 * \\
(0.014)\end{array}$ & $\begin{array}{c}-0.285 * \\
(0.011)\end{array}$ & $\begin{array}{c}-0.255 * \\
(0.008)\end{array}$ & $\begin{array}{c}-0.197 * \\
(0.009)\end{array}$ & $\begin{array}{c}-0.223 * \\
(0.009)\end{array}$ & $\begin{array}{c}-0.189 * \\
(0.008)\end{array}$ \\
\hline$\%$ female in occupation & .. & $\ldots$ & $\ldots$ & ... & $\begin{array}{c}-0.140 * \\
(0.011)\end{array}$ & $\begin{array}{c}-0.034 \\
(0.019)\end{array}$ \\
\hline$\%$ female in job cell & .. & ... & .. & $\ldots$ & $\ldots$ & $\begin{array}{r}-0.162 * \\
(0.017)\end{array}$ \\
\hline Number of workers & 548,381 & 548,381 & 548,381 & 530,807 & 548,381 & 548,381 \\
\hline Number of firms & 571 & 571 & 571 & $6648^{\mathrm{b}}$ & 571 & 571 \\
\hline \multicolumn{7}{|c|}{ Slovak Public Sector } \\
\hline$\overline{\text { Female }}$ & $\begin{array}{c}-0.164 * \\
(0.018)\end{array}$ & $\begin{array}{c}-0.071 * \\
(0.017)\end{array}$ & $\begin{array}{c}-0.072 * \\
(0.018)\end{array}$ & $\begin{array}{c}-0.068 * \\
(0.010)\end{array}$ & $\begin{array}{c}-0.055 * \\
(0.014)\end{array}$ & $\begin{array}{c}-0.050 * \\
(0.010)\end{array}$ \\
\hline$\%$ female in occupation & ... & ... & $\ldots$ & .. & $\begin{array}{l}-0.078 \\
(0.052)\end{array}$ & $\begin{array}{c}-0.067 \\
(0.049)\end{array}$ \\
\hline$\%$ female in job cell & $\ldots$ & $\ldots$ & $\ldots$ & $\ldots$ & $\ldots$ & $\begin{array}{c}-0.025 \\
(0.046)\end{array}$ \\
\hline Number of workers & 13,709 & 13,709 & 13,709 & 13,662 & 13,709 & 13,709 \\
\hline Number of firms & 35 & 35 & 35 & $438^{\mathrm{b}}$ & 35 & 35 \\
\hline \multicolumn{7}{|c|}{ Slovak Non-Public Sector } \\
\hline Female & $\begin{array}{c}-0.208 * \\
(0.014)\end{array}$ & $\begin{array}{c}-0.216 * \\
(0.008)\end{array}$ & $\begin{array}{c}-0.186 * \\
(0.006)\end{array}$ & $\begin{array}{c}-0.162 * \\
(0.007)\end{array}$ & $\begin{array}{c}-0.158 * \\
(0.006)\end{array}$ & $\begin{array}{c}-0.147 * \\
(0.006)\end{array}$ \\
\hline$\%$ female in occupation & $\ldots$ & $\ldots$ & $\ldots$ & $\ldots$ & $\begin{array}{c}-0.124 * \\
(0.013)\end{array}$ & $\begin{array}{c}-0.097 * \\
(0.018)\end{array}$ \\
\hline$\%$ female in job cell & $\ldots$ & $\ldots$ & $\ldots$ & $\ldots$ & $\ldots$ & $\begin{array}{c}-0.058 * \\
(0.016)\end{array}$ \\
\hline Number of workers & 98,989 & 98,989 & 98,989 & 94,130 & 98,989 & 98,989 \\
\hline Number of firms & 408 & 408 & 408 & $3832^{\mathrm{b}}$ & 408 & 408 \\
\hline Weighting & Yes & Yes & Yes & Yes & Yes & Yes \\
\hline Fixed effects & No & No & Firm & Job cell & Firm & Firm \\
\hline Other controls $^{\mathrm{a}}$ & No & Worker's & All & All & All & All \\
\hline
\end{tabular}

* statistically significant at the $1 \%$ level

${ }^{a}$ Other controls: worker's education degrees, age and age square; firm's employment and its square, ownership and 2-digit industry, establishment's region.

${ }^{\mathrm{b}}$ Number of job cell fixed effects. For comparison with column 7 of Table 3, only observations where `\% female supervisors in firm' is available are used.

Note: Standard errors in parenteses. 
Table 1: Weighted Mean Differences in Hourly Wages by Gender

Female wage disadvantage as $\%$ of male wage $\left(1-\mathrm{w}_{\mathrm{f}} / \mathrm{w}_{\mathrm{m}}\right)$

\begin{tabular}{|c|c|c|c|c|c|}
\hline \multirow[b]{2}{*}{ Variable } & & \multicolumn{2}{|c|}{ Czech ISAE } & \multicolumn{2}{|c|}{ Slovak ISAE } \\
\hline & & $\begin{array}{c}\text { Public Sector } \\
\text { (1) }\end{array}$ & $\begin{array}{c}\text { Non-public Sector } \\
\text { (2) }\end{array}$ & $\begin{array}{c}\text { Public Sector } \\
\text { (3) }\end{array}$ & $\begin{array}{c}\text { Non-public Sector } \\
\text { (4) }\end{array}$ \\
\hline \multirow[t]{5}{*}{ Education } & Primary & 0.123 & 0.234 & 0.233 & 0.178 \\
\hline & Secondary without GCE & 0.179 & 0.269 & 0.078 & 0.239 \\
\hline & Secondary with GCE & 0.137 & 0.263 & -0.062 & 0.187 \\
\hline & University & 0.163 & 0.327 & 0.165 & 0.200 \\
\hline & Post-graduate & 0.209 & 0.221 & 0.018 & 0.310 \\
\hline \multirow[t]{6}{*}{ Age } & -19 & -0.026 & 0.142 & -0.078 & 0.113 \\
\hline & $20-29$ & 0.183 & 0.198 & -0.022 & 0.180 \\
\hline & $30-39$ & 0.301 & 0.301 & 0.093 & 0.219 \\
\hline & $40-49$ & 0.286 & 0.292 & 0.213 & 0.221 \\
\hline & $50-59$ & 0.195 & 0.270 & 0.215 & 0.222 \\
\hline & $60-$ & -0.100 & 0.120 & 0.114 & 0.417 \\
\hline \multirow[t]{6}{*}{ Ownership } & Foreign & - & 0.280 & - & 0.280 \\
\hline & Private & - & 0.258 & - & 0.249 \\
\hline & Co-operative & - & 0.211 & - & 0.116 \\
\hline & State & - & 0.293 & - & 0.162 \\
\hline & Mixed & - & 0.213 & - & 0.129 \\
\hline & Public Sector & 0.237 & - & 0.168 & - \\
\hline \multirow[t]{3}{*}{ Firm size } & 100-249 Employees & 0.223 & 0.237 & 0.135 & 0.171 \\
\hline & 250-499 Employees & 0.172 & 0.250 & & \\
\hline & $\begin{array}{l}\text { 500-999 Employees } \\
\text { Over } 1000 \text { Employees }\end{array}$ & $\begin{array}{l}0.209 \\
0.268\end{array}$ & $\begin{array}{l}0.267 \\
0.285\end{array}$ & $\begin{array}{l}0.206 \\
0.181\end{array}$ & $\begin{array}{l}0.254 \\
0.233\end{array}$ \\
\hline \multirow{2}{*}{\multicolumn{2}{|c|}{$\begin{array}{l}\text { Number of workers } \\
\text { Number of firms }\end{array}$}} & 178,209 & 548,381 & 13,709 & 98,989 \\
\hline & & 92 & 571 & 35 & 408 \\
\hline
\end{tabular}


Table 2: Estimated Log Wage Differentials by Sex - WLS Regressions

\begin{tabular}{|c|c|c|c|c|c|}
\hline & (1) & $(2)$ & (3) & (4) & (5) \\
\hline \multicolumn{6}{|c|}{ Czech Public Sector } \\
\hline \multirow[t]{2}{*}{ Female } & -0.241 & -0.180 & -0.155 & -0.156 & -0.103 \\
\hline & $(0.044)$ & $(0.04)$ & $(0.021)$ & $(0.023)$ & $(0.006)$ \\
\hline R-squared & 0.073 & 0.571 & 0.586 & 0.621 & 0.726 \\
\hline Number of workers & 178,209 & 178,209 & 178,209 & 178,209 & 163,072 \\
\hline Number of firms & 92 & 92 & 92 & 92 & $913^{\mathrm{b}}$ \\
\hline \multicolumn{6}{|c|}{ Czech Non-Public Sector } \\
\hline \multirow[t]{2}{*}{ Female } & -0.297 & -0.315 & -0.266 & -0.247 & -0.200 \\
\hline & $(0.014)$ & $(0.013)$ & $(0.011)$ & $(0.009)$ & $(0.009)$ \\
\hline R-squared & 0.107 & 0.385 & 0.490 & 0.596 & 0.715 \\
\hline Number of workers & 548,381 & 548,381 & 548,381 & 548,381 & 530,807 \\
\hline Number of firms & 571 & 571 & 571 & 571 & $6648^{\mathrm{b}}$ \\
\hline \multicolumn{6}{|c|}{ Slovak Public Sector } \\
\hline \multirow[t]{2}{*}{ Female } & -0.152 & -0.082 & -0.076 & -0.078 & -0.069 \\
\hline & $(0.023)$ & $(0.023)$ & $(0.019)$ & $(0.018)$ & $(0.016)$ \\
\hline R-squared & 0.025 & 0.530 & 0.653 & 0.676 & 0.823 \\
\hline Number of workers & 13,709 & 13,709 & 13,709 & 13,709 & 13,662 \\
\hline Number of firms & 35 & 35 & 35 & 35 & $438^{\mathrm{b}}$ \\
\hline \multicolumn{6}{|c|}{ Slovak Non-Public Sector } \\
\hline \multirow{2}{*}{ Female } & -0.227 & -0.231 & -0.204 & -0.179 & -0.161 \\
\hline & $(0.014)$ & $(0.014)$ & $(0.008)$ & $(0.007)$ & $(0.008)$ \\
\hline R-squared & 0.064 & 0.287 & 0.476 & 0.600 & 0.703 \\
\hline Number of workers & 98,989 & 98,989 & 98,989 & 98,989 & 94,130 \\
\hline Number of firms & 408 & 408 & 408 & 408 & $3832^{\mathrm{b}}$ \\
\hline Fixed effects & No & No & No & Firm & Job cell \\
\hline Other controls $^{\mathrm{a}}$ & No & Worker's & All & All & All \\
\hline
\end{tabular}

a Other controls: worker's education degrees, age and age square; firm's employment and its square ownership and 2-digit industry, establishment's region.

${ }^{\mathrm{b}}$ Number of job cell fixed effects. For comparison with columns (4) and (10) of Table 3, only observations where '\% female supervisors in firm' is available are used

Note: Standard errors in parenteses; all reported estimates statistically significant at the $1 \%$ level. 
Table 3: Estimated Log Wage Differentials by Sex, and Percent Female in Occupation, Firm, Job Cell, and Supervisors within Firm: WLS Regressions

\begin{tabular}{|c|c|c|c|c|c|c|c|c|c|c|c|c|}
\hline & $(1)$ & $(2)$ & (3) & (4) & $(5)$ & (6) & $(7)$ & $(8)$ & $(9)$ & $(10)$ & $(11)$ & $(12)$ \\
\hline & \multicolumn{6}{|c|}{ Czech Public Sector } & \multicolumn{6}{|c|}{ Slovak Public Sector } \\
\hline Female & $\begin{array}{c}-0.126 * \\
(0.012)\end{array}$ & $\begin{array}{c}-0.102 * \\
(0.007)\end{array}$ & $\begin{array}{c}-0.092 * \\
(0.006)\end{array}$ & $\begin{array}{c}-0.092 * \\
(0.007)\end{array}$ & $\begin{array}{c}-0.086 * \\
(0.008)\end{array}$ & $\begin{array}{c}-0.078 * \\
(0.019)\end{array}$ & $\begin{array}{c}-0.073 * \\
(0.016)\end{array}$ & $\begin{array}{c}-0.058 * \\
(0.014)\end{array}$ & $\begin{array}{c}-0.052 * \\
(0.010)\end{array}$ & $\begin{array}{c}-0.060 * \\
(0.014)\end{array}$ & $\begin{array}{c}-0.043 * \\
(0.013)\end{array}$ & $\begin{array}{c}-0.009 \\
(0.022)\end{array}$ \\
\hline$\%$ female in occupation & $\begin{array}{c}-0.162 * \\
(0.035)\end{array}$ & $\begin{array}{c}-0.101 * \\
(0.031)\end{array}$ & $\begin{array}{l}-0.045 \\
(0.033)\end{array}$ & $\begin{array}{c}-0.100 * \\
(0.029)\end{array}$ & $\begin{array}{l}-0.095 \\
(0.039)\end{array}$ & $\begin{array}{l}-0.106 \\
(0.061)\end{array}$ & $\begin{array}{c}-0.018 \\
(0.041)\end{array}$ & $\begin{array}{c}0.019 \\
(0.053)\end{array}$ & $\begin{array}{l}-0.151 \\
(0.068)\end{array}$ & $\begin{array}{c}0.006 \\
(0.056)\end{array}$ & $\begin{array}{l}-0.104 \\
(0.105)\end{array}$ & $\begin{array}{c}0.539 * \\
(0.103)\end{array}$ \\
\hline$\%$ female in job cell & $\ldots$ & $\begin{array}{c}-0.105 * \\
(0.035)\end{array}$ & $\begin{array}{c}-0.123 * \\
(0.037)\end{array}$ & $\begin{array}{c}-0.155 * \\
(0.041)\end{array}$ & $\begin{array}{c}-0.201 * \\
(0.046)\end{array}$ & $\begin{array}{l}-0.032 \\
(0.061)\end{array}$ & $\ldots$ & $\begin{array}{l}-0.061 \\
(0.039)\end{array}$ & $\begin{array}{c}0.038 \\
(0.052)\end{array}$ & $\begin{array}{l}-0.057 \\
(0.044)\end{array}$ & $\begin{array}{c}-0.008 \\
(0.069)\end{array}$ & $\begin{array}{c}-0.272 * \\
(0.080)\end{array}$ \\
\hline$\%$ female in firm & $\cdots$ & $\cdots$ & $\cdots$ & $\begin{array}{c}0.019 \\
(0.110)\end{array}$ & $\begin{array}{c}0.045 \\
(0.106)\end{array}$ & $\begin{array}{c}-0.004 \\
(0.137)\end{array}$ & $\cdots$ & $\cdots$ & $\cdots$ & $\begin{array}{c}-0.352 * \\
(0.112)\end{array}$ & $\begin{array}{l}-0.259 \\
(0.158)\end{array}$ & $\begin{array}{c}-0.530 * \\
(0.183)\end{array}$ \\
\hline$\%$ female supervisors in firm & $\ldots$ & $\ldots$ & $\ldots$ & $\begin{array}{c}0.075 \\
(0.062)\end{array}$ & $\begin{array}{c}0.100 \\
(0.063)\end{array}$ & $\begin{array}{c}0.009 \\
(0.068)\end{array}$ & $\ldots$ & $\ldots$ & $\ldots$ & $\begin{array}{l}0.301 * \\
(0.056)\end{array}$ & $\begin{array}{l}0.221 * \\
(0.059)\end{array}$ & $\begin{array}{c}0.471 * \\
(0.095)\end{array}$ \\
\hline R-squared & 0.591 & 0.593 & 0.592 & 0.597 & 0.606 & 0.442 & 0.653 & 0.654 & 0.657 & 0.668 & 0.685 & 0.500 \\
\hline Number of workers & 178,209 & 178,209 & 178,209 & 163,072 & 61,011 & 24,108 & 13,709 & 13,709 & 13,709 & 13,662 & 5,348 & 1,588 \\
\hline \multirow[t]{2}{*}{ Number of firms } & 92 & 92 & 92 & 71 & 71 & 71 & 35 & 35 & 35 & 34 & 34 & 34 \\
\hline & \multicolumn{6}{|c|}{ Czech Non-Public Sector } & \multicolumn{6}{|c|}{ Slovak Non-Public Sector } \\
\hline Female & $\begin{array}{c}-0.228 * \\
(0.013)\end{array}$ & $\begin{array}{c}-0.188 * \\
(0.008)\end{array}$ & $\begin{array}{c}-0.158 * \\
(0.007)\end{array}$ & $\begin{array}{c}-0.190 * \\
(0.009)\end{array}$ & $\begin{array}{c}-0.177 * \\
(0.009)\end{array}$ & $\begin{array}{c}-0.134 * \\
(0.010)\end{array}$ & $\begin{array}{c}-0.177 * \\
(0.009)\end{array}$ & $\begin{array}{c}-0.140 * \\
(0.007)\end{array}$ & $\begin{array}{c}-0.126 * \\
(0.007)\end{array}$ & $\begin{array}{c}-0.140 * \\
(0.007)\end{array}$ & $\begin{array}{c}-0.128 * \\
(0.009)\end{array}$ & $\begin{array}{c}-0.108 * \\
(0.011)\end{array}$ \\
\hline$\%$ female in occupation & $\begin{array}{c}-0.152 * \\
(0.028)\end{array}$ & $\begin{array}{l}-0.058 \\
(0.049)\end{array}$ & $\begin{array}{l}-0.056 \\
(0.034)\end{array}$ & $\begin{array}{l}-0.104 \\
(0.048)\end{array}$ & $\begin{array}{c}-0.148 * \\
(0.054)\end{array}$ & $\begin{array}{l}-0.157 \\
(0.061)\end{array}$ & $\begin{array}{c}-0.136 * \\
(0.018)\end{array}$ & $\begin{array}{c}-0.072 * \\
(0.026)\end{array}$ & $\begin{array}{c}-0.081 * \\
(0.023)\end{array}$ & $\begin{array}{c}-0.098 * \\
(0.025)\end{array}$ & $\begin{array}{c}-0.146 * \\
(0.026)\end{array}$ & $\begin{array}{l}-0.006 \\
(0.031)\end{array}$ \\
\hline$\%$ female in job cell & $\ldots$ & $\begin{array}{c}-0.160 * \\
(0.040)\end{array}$ & $\begin{array}{c}-0.162 * \\
(0.029)\end{array}$ & $\begin{array}{c}-0.104 * \\
(0.039)\end{array}$ & $\begin{array}{l}-0.112 \\
(0.045)\end{array}$ & $\begin{array}{l}-0.019 \\
(0.047)\end{array}$ & $\cdots$ & $\begin{array}{c}-0.124 * \\
(0.026)\end{array}$ & $\begin{array}{c}-0.104 * \\
(0.023)\end{array}$ & $\begin{array}{c}-0.060 * \\
(0.019)\end{array}$ & $\begin{array}{c}-0.075 * \\
(0.024)\end{array}$ & $\begin{array}{l}-0.054 \\
(0.026)\end{array}$ \\
\hline$\%$ female in firm & $\cdots$ & $\cdots$ & $\cdots$ & $\begin{array}{c}-0.237 * \\
(0.085)\end{array}$ & $\begin{array}{l}-0.244 * \\
(0.087)\end{array}$ & $\begin{array}{l}-0.205 \\
(0.097)\end{array}$ & $\ldots$ & $\cdots$ & $\ldots$ & $\begin{array}{l}-0.175 \\
(0.073)\end{array}$ & $\begin{array}{l}-0.118 \\
(0.078)\end{array}$ & $\begin{array}{l}-0.169 \\
(0.073)\end{array}$ \\
\hline$\%$ female supervisors in firm & $\cdots$ & $\cdots$ & $\ldots$ & $\begin{array}{l}-0.014 \\
(0.048)\end{array}$ & $\begin{array}{l}-0.007 \\
(0.052)\end{array}$ & $\begin{array}{l}-0.030 \\
(0.053)\end{array}$ & $\cdots$ & $\cdots$ & $\cdots$ & $\begin{array}{l}-0.103 \\
(0.041)\end{array}$ & $\begin{array}{l}-0.154 * \\
(0.048)\end{array}$ & $\begin{array}{l}-0.063 \\
(0.038)\end{array}$ \\
\hline R-squared & 0.495 & 0.499 & 0.500 & 0.512 & 0.513 & 0.436 & 0.481 & 0.484 & 0.483 & 0.491 & 0.531 & 0.430 \\
\hline Number of workers & 548,381 & 548,381 & 548,381 & 530,807 & 211,218 & 87,761 & 98,989 & 98,989 & 98,989 & 94,130 & 31,756 & 12,927 \\
\hline Number of firms & 571 & 571 & 571 & 527 & 523 & 527 & 408 & 408 & 408 & 390 & 386 & 387 \\
\hline $\begin{array}{l}\text { Occupational classification } \\
\text { Age cohorts }\end{array}$ & $\begin{array}{c}\text { 2-digit } \\
\text { All } \\
\end{array}$ & $\begin{array}{c}\text { 2-digit } \\
\text { All } \\
\end{array}$ & $\begin{array}{l}\text { 4-digit } \\
\text { All } \\
\end{array}$ & $\begin{array}{c}\text { 2-digit } \\
\text { All } \\
\end{array}$ & $\begin{array}{c}\text { 2-digit } \\
>45\end{array}$ & $\begin{array}{l}2 \text {-digit } \\
<25\end{array}$ & $\begin{array}{c}\text { 2-digit } \\
\text { All } \\
\end{array}$ & $\begin{array}{c}\text { 2-digit } \\
\text { All } \\
\end{array}$ & $\begin{array}{l}\text { 4-digit } \\
\text { All } \\
\end{array}$ & $\begin{array}{c}\text { 2-digit } \\
\text { All } \\
\end{array}$ & $\begin{array}{c}2 \text {-digit } \\
>45\end{array}$ & $\begin{array}{c}2 \text {-digit } \\
<25 \\
\end{array}$ \\
\hline
\end{tabular}

* statistically significant at the $1 \%$ level

Note: Standard errors in parentheses. All specifications include the following set of control variables: workers' education degrees, age and age square; firms' employment and its square, ownership and 2-digit industry, establishments' region. No fixed effects are used in any of the specifications. 
Table 4: Wage Gap Decomposition for Czech Public Sector

\begin{tabular}{|c|c|c|c|c|c|}
\hline Variable & $\begin{array}{l}\text { Coefficient } \\
\text { estimate } \\
(1) \\
\end{array}$ & $\begin{array}{l}\text { Coefficient } \\
\text { estimate } \\
(2) \\
\end{array}$ & $\begin{array}{c}\text { Mean difference } \\
\text { women - men } \\
\text { (3) }\end{array}$ & $\begin{array}{c}\text { Absolute } \\
\text { contribution to } \\
\text { wage gap, (2) x (3) }\end{array}$ & $\begin{array}{c}\text { Relative contribution } \\
\text { to wage gap } \\
(2) \mathrm{x}(3) /(1) \\
\end{array}$ \\
\hline Female & $\begin{array}{l}-0.241 * \\
(0.044)\end{array}$ & $\begin{array}{l}-0.092 * \\
(0.007)\end{array}$ & 1.000 & -0.092 & 0.382 \\
\hline$\%$ female in occupation & $\ldots$ & $\begin{array}{c}-0.1 * \\
(0.029)\end{array}$ & 0.287 & -0.029 & 0.118 \\
\hline$\%$ female in job cell & $\ldots$ & $\begin{array}{r}-0.155 * \\
(0.041)\end{array}$ & 0.455 & -0.070 & 0.292 \\
\hline$\%$ female in firm & $\ldots$ & $\begin{array}{l}0.019 \\
(0.11)\end{array}$ & 0.190 & 0.004 & -0.015 \\
\hline $\begin{array}{l}\% \text { female supervisors in } \\
\text { firm }\end{array}$ & $\ldots$ & $\begin{array}{c}0.075 \\
(0.062)\end{array}$ & 0.235 & 0.018 & -0.073 \\
\hline Age & $\ldots$ & $\begin{array}{l}0.038 * \\
(0.003)\end{array}$ & 3.212 & 0.123 & -0.509 \\
\hline Age squared & $\ldots$ & $\begin{array}{c}-0.036 * \\
(0.003)\end{array}$ & 1.470 & -0.052 & 0.217 \\
\hline Firm employment/1000 & $\ldots$ & $\begin{array}{c}0.005 \\
(0.004)\end{array}$ & 11.297 & 0.057 & -0.234 \\
\hline$\left(\right.$ Firm empl./10000) ${ }^{2}$ & $\cdots$ & $\begin{array}{l}-0.005 \\
(0.005)\end{array}$ & 12.084 & -0.065 & 0.269 \\
\hline $\begin{array}{l}\text { Secondary education } \\
\text { without GCE }\end{array}$ & $\ldots$ & $\begin{array}{l}0.117 * \\
(0.012)\end{array}$ & -0.037 & -0.004 & 0.018 \\
\hline $\begin{array}{l}\text { Secondary education with } \\
\text { GCE }\end{array}$ & $\ldots$ & $\begin{array}{l}0.494 * \\
(0.017)\end{array}$ & 0.253 & 0.125 & -0.518 \\
\hline University education & $\ldots$ & $\begin{array}{l}0.717 * \\
(0.025)\end{array}$ & -0.225 & -0.162 & 0.670 \\
\hline Post-graduate education & $\ldots$ & $\begin{array}{l}0.893 * \\
(0.028) \\
\end{array}$ & -0.034 & -0.030 & 0.124 \\
\hline R-squared & 0.094 & 0.632 & & & \\
\hline Number of workers & 178,209 & 163,072 & & & \\
\hline Number of firms & 92 & 71 & & & \\
\hline
\end{tabular}

Note: Column (1) comes from column (1) of Table 2; column (2) comes from column (4) of Table 3. The mean differences and coefficients for the regional and 2-digit industrial dummies are not reported but are included in the calculations. 
Table 5: Wage Gap Decomposition for Czech Non-public Sector

\begin{tabular}{|c|c|c|c|c|c|}
\hline Variable & $\begin{array}{l}\text { Coefficient } \\
\text { estimate } \\
\text { (1) }\end{array}$ & $\begin{array}{l}\text { Coefficient } \\
\text { estimate } \\
\text { (2) }\end{array}$ & $\begin{array}{c}\text { Mean difference } \\
\text { women - men } \\
\text { (3) }\end{array}$ & $\begin{array}{c}\text { Absolute } \\
\text { contribution to } \\
\text { wage gap, (2) x (3) }\end{array}$ & $\begin{array}{l}\text { Relative contribution } \\
\text { to wage gap } \\
\text { (2) } \mathrm{x}(3) /(1)\end{array}$ \\
\hline Female & $\begin{array}{l}-0.297 * \\
(0.014)\end{array}$ & $\begin{array}{l}-0.19 * \\
(0.009)\end{array}$ & 1.000 & -0.190 & 0.639 \\
\hline$\%$ female in occupation & $\ldots$ & $\begin{array}{l}-0.104 \\
(0.048)\end{array}$ & 0.328 & -0.034 & 0.115 \\
\hline$\%$ female in job cell & $\ldots$ & $\begin{array}{l}-0.104 * \\
(0.039)\end{array}$ & 0.512 & -0.053 & 0.180 \\
\hline$\%$ female in firm & $\ldots$ & $\begin{array}{l}-0.237 * \\
(0.085)\end{array}$ & 0.236 & -0.056 & 0.188 \\
\hline $\begin{array}{l}\% \text { female supervisors in } \\
\text { firm }\end{array}$ & $\ldots$ & $\begin{array}{l}-0.014 \\
(0.048)\end{array}$ & 0.166 & -0.002 & 0.008 \\
\hline Age & $\ldots$ & $\begin{array}{l}0.031 * \\
(0.001)\end{array}$ & -0.169 & -0.005 & 0.018 \\
\hline Age squared & $\ldots$ & $\begin{array}{l}-0.034 * \\
(0.002)\end{array}$ & -0.125 & 0.004 & -0.014 \\
\hline Firm employment/1000 & $\ldots$ & $\begin{array}{c}0.009 \\
(0.005)\end{array}$ & -0.634 & -0.006 & 0.020 \\
\hline$(\text { Firm empl./10000) })^{2}$ & .. & $\begin{array}{c}-0.015 \\
(0.0001)\end{array}$ & -0.144 & 0.002 & -0.007 \\
\hline $\begin{array}{l}\text { Secondary education } \\
\text { without GCE }\end{array}$ & $\ldots$ & $\begin{array}{l}0.116 * \\
(0.013)\end{array}$ & -0.139 & -0.016 & 0.054 \\
\hline $\begin{array}{l}\text { Secondary education with } \\
\text { GCE }\end{array}$ & $\cdots$ & $\begin{array}{l}0.386 * \\
(0.012)\end{array}$ & 0.122 & 0.047 & -0.159 \\
\hline University education & $\ldots$ & $\begin{array}{l}0.722 * \\
(0.031)\end{array}$ & -0.029 & -0.021 & 0.069 \\
\hline Post-graduate education & $\ldots$ & $\begin{array}{l}0.852 * \\
(0.049)\end{array}$ & -0.004 & -0.003 & 0.011 \\
\hline Ownership Private & $\ldots$ & $\begin{array}{l}-0.086 * \\
(0.027)\end{array}$ & -0.046 & 0.004 & -0.013 \\
\hline Co-operative & $\ldots$ & $\begin{array}{l}-0.232 * \\
(0.052)\end{array}$ & 0.054 & -0.012 & 0.042 \\
\hline State & $\ldots$ & $\begin{array}{c}-0.114 * \\
(0.032)\end{array}$ & -0.013 & 0.001 & -0.005 \\
\hline Mixed & $\ldots$ & $\begin{array}{c}0.025 \\
(0.082)\end{array}$ & -0.003 & 0.000 & 0.000 \\
\hline R-squared & 0.107 & 0.501 & & & \\
\hline Number of workers & 548,381 & 530,807 & & & \\
\hline Number of firms & 571 & 527 & & & \\
\hline
\end{tabular}

Note: Column (1) comes from column (1) of Table 2; column (2) comes from column (4) of Table 3. The mean differences and coefficients for the regional and 2-digit industrial dummies are not reported but are included in the calculations. 
Table 6: Wage Gap Decomposition for Slovak Public Sector

\begin{tabular}{|c|c|c|c|c|c|}
\hline Variable & $\begin{array}{l}\text { Coefficient } \\
\text { estimate } \\
(1) \\
\end{array}$ & $\begin{array}{l}\text { Coefficient } \\
\text { estimate } \\
(2) \\
\end{array}$ & $\begin{array}{c}\text { Mean difference } \\
\text { women - men } \\
(3)\end{array}$ & $\begin{array}{c}\text { Absolute } \\
\text { contribution to } \\
\text { wage gap, (2) x (3) }\end{array}$ & $\begin{array}{c}\text { Relative contribution } \\
\text { to wage gap } \\
(2) \mathrm{x}(3) /(1) \\
\end{array}$ \\
\hline Female & $\begin{array}{l}-0.152 * \\
(0.023)\end{array}$ & $\begin{array}{l}-0.06 * \\
(0.014)\end{array}$ & 1.000 & -0.060 & 0.395 \\
\hline$\%$ female in occupation & $\ldots$ & $\begin{array}{c}0.006 \\
(0.056)\end{array}$ & 0.168 & 0.001 & -0.007 \\
\hline$\%$ female in job cell & $\cdots$ & $\begin{array}{l}-0.057 \\
(0.044)\end{array}$ & 0.396 & -0.023 & 0.148 \\
\hline$\%$ female in firm & $\cdots$ & $\begin{array}{l}-0.352 * \\
(0.112)\end{array}$ & 0.083 & -0.029 & 0.191 \\
\hline $\begin{array}{l}\% \text { female supervisors in } \\
\text { firm }\end{array}$ & $\ldots$ & $\begin{array}{l}0.301 * \\
(0.056)\end{array}$ & 0.088 & 0.027 & -0.174 \\
\hline Age & $\ldots$ & $\begin{array}{l}0.031 * \\
(0.002)\end{array}$ & -3.573 & -0.110 & 0.718 \\
\hline Age squared & $\ldots$ & $\begin{array}{c}-0.029 * \\
(0.003)\end{array}$ & -3.452 & 0.101 & -0.662 \\
\hline Firm employment/1000 & $\cdots$ & $\begin{array}{l}-0.024 \\
(0.038)\end{array}$ & -0.040 & 0.001 & -0.006 \\
\hline$(\text { Firm empl./1000) })^{2}$ & $\cdots$ & $\begin{array}{c}0.027 \\
(0.023)\end{array}$ & -0.111 & -0.003 & 0.020 \\
\hline $\begin{array}{l}\text { Secondary education } \\
\text { without GCE }\end{array}$ & $\ldots$ & $\begin{array}{l}0.198 * \\
(0.025)\end{array}$ & -0.109 & -0.022 & 0.142 \\
\hline $\begin{array}{l}\text { Secondary education with } \\
\text { GCE }\end{array}$ & $\ldots$ & $\begin{array}{l}0.465 * \\
(0.027)\end{array}$ & 0.304 & 0.141 & -0.928 \\
\hline University education & $\cdots$ & $\begin{array}{l}0.825 * \\
(0.031)\end{array}$ & -0.129 & -0.107 & 0.701 \\
\hline $\begin{array}{l}\text { Post-graduate education } \\
\text { misssex }\end{array}$ & $\ldots$ & $\begin{array}{l}0.966 * \\
(0.102) \\
(0.021) \\
\end{array}$ & -0.121 & -0.116 & 0.764 \\
\hline R-squared & 0.039 & 0.630 & & & \\
\hline Number of workers & 13,709 & 13,662 & & & \\
\hline Number of firms & 35 & 34 & & & \\
\hline
\end{tabular}

Note: Column (1) comes from column (1) of Table 2; column (2) comes from column (10) of Table 3. The mean differences and coefficients for the regional and 2-digit industrial dummies are not reported but are included in the calculations. 
Table 7: Wage Gap Decomposition for Slovak Non-public Sector

\begin{tabular}{|c|c|c|c|c|c|}
\hline Variable & $\begin{array}{l}\text { Coefficient } \\
\text { estimate } \\
(1) \\
\end{array}$ & $\begin{array}{l}\text { Coefficient } \\
\text { estimate } \\
(2) \\
\end{array}$ & $\begin{array}{c}\text { Mean difference } \\
\text { women - men } \\
(3) \\
\end{array}$ & $\begin{array}{c}\text { Absolute } \\
\text { contribution to } \\
\text { wage gap, }(2) \times(3)\end{array}$ & $\begin{array}{l}\text { Relative contribution } \\
\text { to wage gap } \\
\text { (2) } \mathrm{x}(3) /(1)\end{array}$ \\
\hline Female & $\begin{array}{l}-0.227 * \\
(0.014)\end{array}$ & $\begin{array}{l}-0.14 * \\
(0.007)\end{array}$ & 1.000 & -0.140 & 0.616 \\
\hline$\%$ female in occupation & $\ldots$ & $\begin{array}{l}-0.098^{*} \\
(0.025)\end{array}$ & 0.252 & -0.025 & 0.109 \\
\hline$\%$ female in job cell & $\cdots$ & $\begin{array}{l}-0.06 * \\
(0.019)\end{array}$ & 0.489 & -0.029 & 0.130 \\
\hline$\%$ female in firm & $\ldots$ & $\begin{array}{l}-0.1748 \\
(0.073)\end{array}$ & 0.211 & -0.037 & 0.162 \\
\hline $\begin{array}{l}\% \text { female supervisors in } \\
\text { firm }\end{array}$ & $\ldots$ & $\begin{array}{l}-0.1034 \\
(0.041)\end{array}$ & 0.153 & -0.016 & 0.070 \\
\hline Age & $\cdots$ & $\begin{array}{l}0.036 * \\
(0.002)\end{array}$ & -0.684 & -0.024 & 0.108 \\
\hline Age squared & $\ldots$ & $\begin{array}{l}-0.038 * \\
(0.002)\end{array}$ & -0.658 & 0.025 & -0.111 \\
\hline Firm employment/1000 & $\cdots$ & $\begin{array}{l}0.066 * \\
(0.011)\end{array}$ & -0.621 & -0.041 & 0.182 \\
\hline$(\text { Firm empl./1000) })^{2}$ & $\ldots$ & $\begin{array}{c}-0.009 * \\
(0.002)\end{array}$ & -1.821 & 0.016 & -0.069 \\
\hline $\begin{array}{l}\text { Secondary education } \\
\text { without GCE }\end{array}$ & $\ldots$ & $\begin{array}{l}0.085 * \\
(0.01)\end{array}$ & -0.141 & -0.012 & 0.053 \\
\hline $\begin{array}{l}\text { Secondary education with } \\
\text { GCE }\end{array}$ & $\ldots$ & $\begin{array}{l}0.251 * \\
(0.013)\end{array}$ & 0.090 & 0.023 & -0.099 \\
\hline University education & $\cdots$ & $\begin{array}{l}0.631 * \\
(0.032)\end{array}$ & -0.023 & -0.014 & 0.063 \\
\hline Post-graduate education & $\ldots$ & $\begin{array}{l}0.827 * \\
(0.079)\end{array}$ & -0.002 & -0.001 & 0.006 \\
\hline Ownership Private & $\ldots$ & $\begin{array}{l}-0.095 \\
(0.046)\end{array}$ & 0.000 & 0.000 & 0.000 \\
\hline Co-operative & $\cdots$ & $\begin{array}{l}-0.18 * \\
(0.067)\end{array}$ & 0.030 & -0.005 & 0.024 \\
\hline State & $\cdots$ & $\begin{array}{c}-0.157 * \\
(0.049)\end{array}$ & -0.006 & 0.001 & -0.004 \\
\hline Mixed & $\ldots$ & $\begin{array}{r}-0.0304 \\
(0.057) \\
\end{array}$ & -0.036 & 0.001 & -0.005 \\
\hline R-squared & 0.079 & 0.521 & & & \\
\hline Number of workers & 98,989 & 94,130 & & & \\
\hline Number of firms & 408 & 390 & & & \\
\hline
\end{tabular}




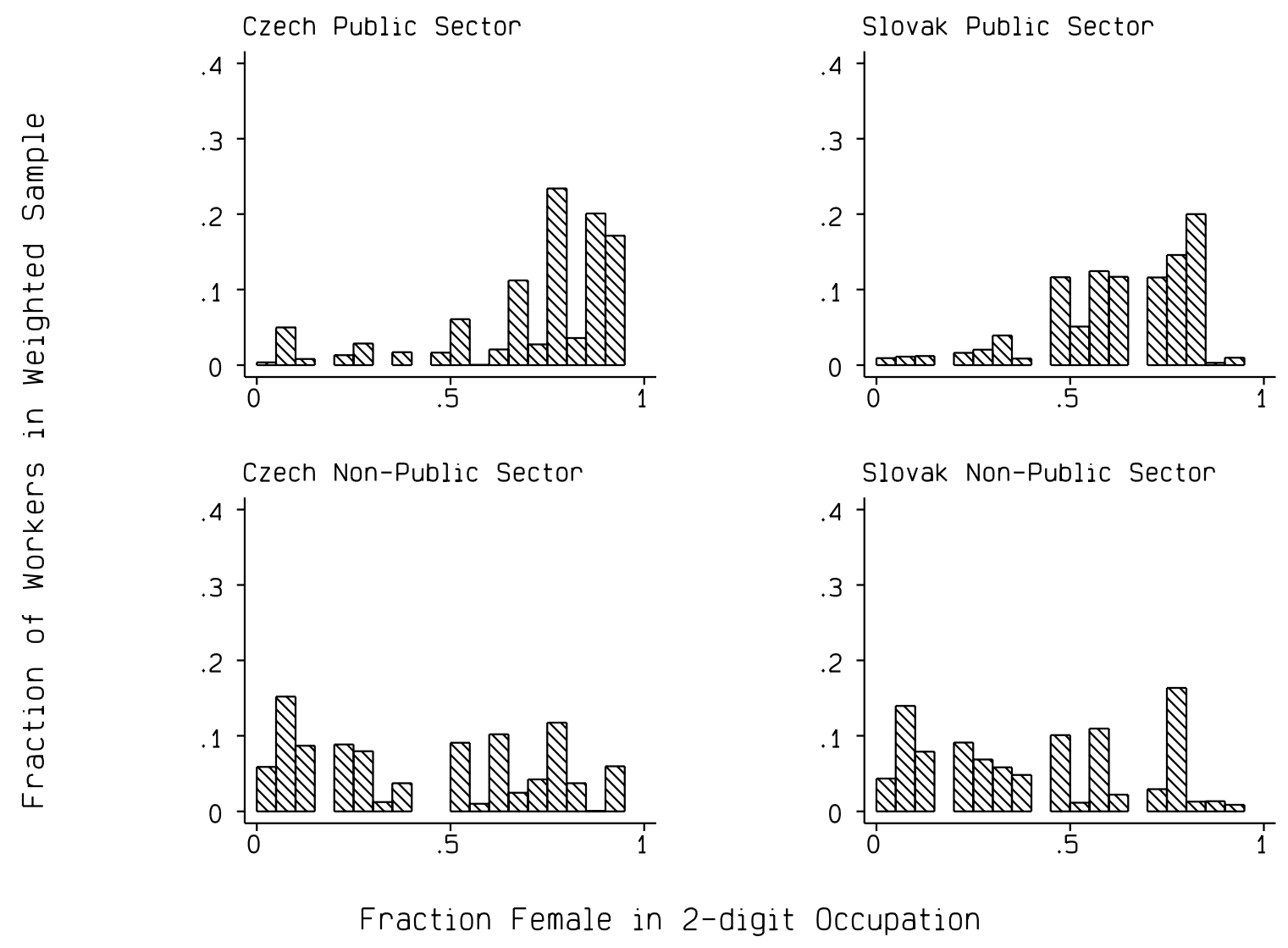

Figure 1: Distribution of Occupational Segregation 


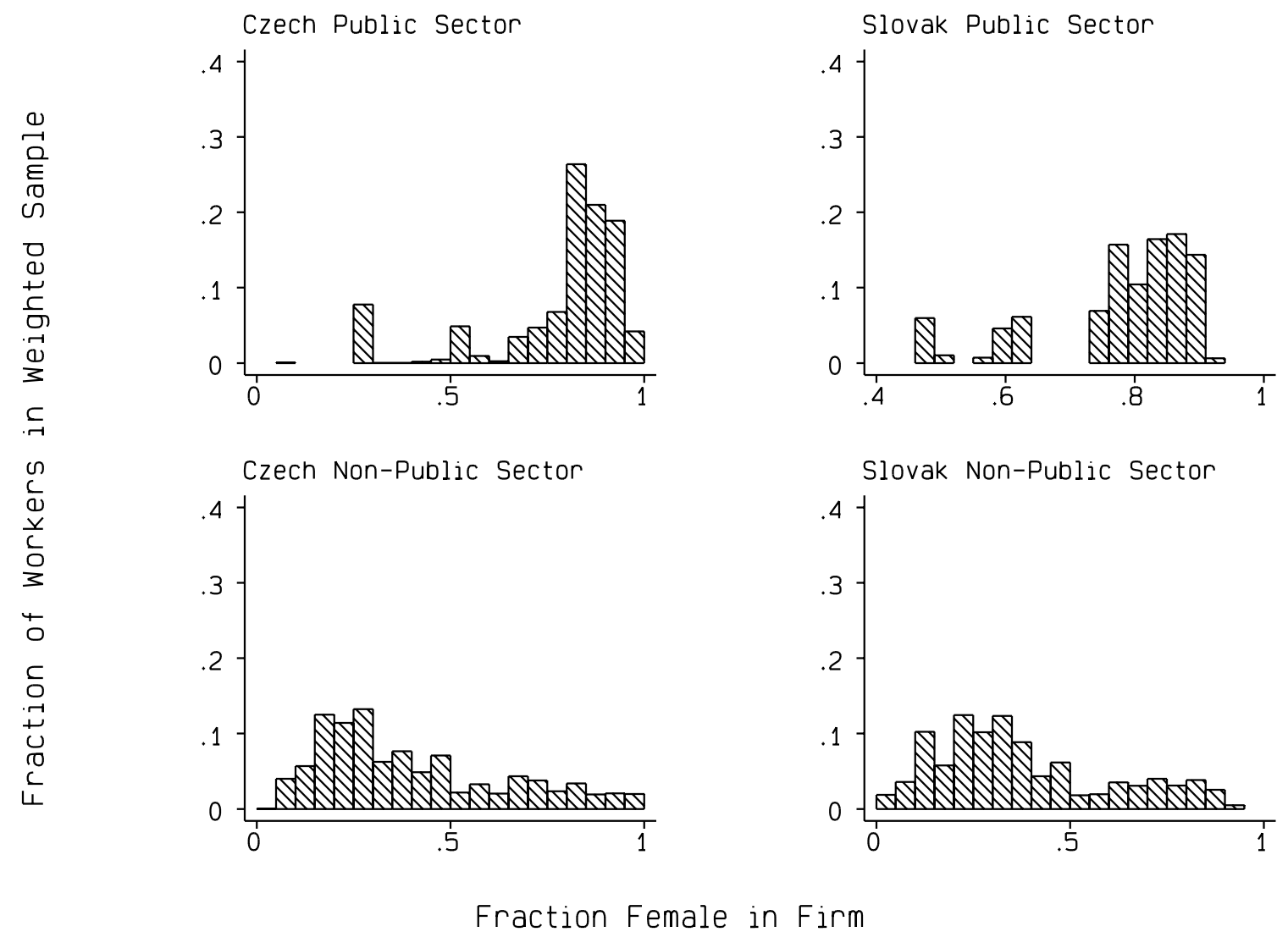

Figure 2: Distribution of Firm Segregation 


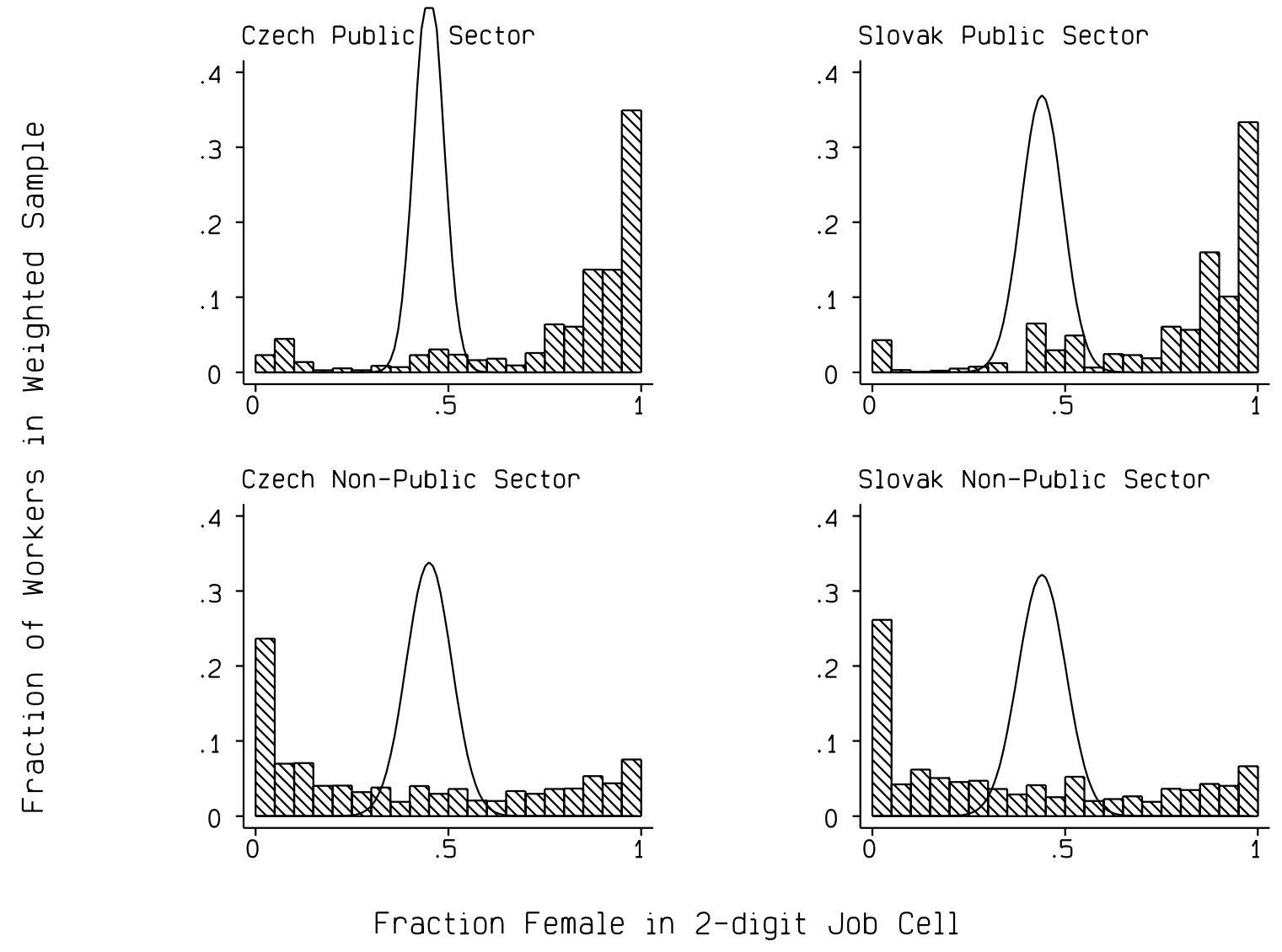

Figure 3: Distribution of Job-Cell Segregation 